Est Ag 47 (2012) 211-245

\title{
III. La compasión en las parábolas más emblemáticas de Lucas
}

\author{
JAVIER ANTOLÍN SÁNCHEZ*
}

RESUMEN: La tercera parte del ensayo estudia la compasión en el Nuevo Testamento, y más en concreto, en las parábolas del Hijo pródigo y del buen Samaritano de San Lucas. Analizamos estas dos parábolas donde de una manera diáfana se manifiesta la misericordia de Dios. Dios es un Padre que se conmueve al ver al hijo que había perdido y echa a correr, le abraza y le besa como una madre. El Samaritano es presentado como modelo de actuación, pues al ver al hombre herido junto al camino se conmovió y practicó la misericordia. En los dos ejemplos la mirada antecede a la conmoción interior. Estos dos textos del Evangelio nos enseñan que las entrañas duelen y se conmueven cuando se abren los ojos ante el sufrimiento de las personas y que la misericordia conlleva una acción, no puede quedar en un mero sentimiento.

PALABRAS CLAVE: Compasión, parábola, hijo pródigo y buen samaritano.

ABSTRACT: The third part of the essay studies the compassion in the New Testament, and concretely, in the parables of the prodigal Son and the good Samaritan of Saint Luke. We study these two parables where in a clear way is manifested the mercy of God. God is a father who moves with compassion seeing the son who had lost and he runs to him, embraces and kisses him as a mother. The Samaritan is presented as a model of action, because seeing the man wounded on the way is moved with compassion and practiced the mercy with him. In both examples the sight precedes the internal feeling. Both evangelical texts teach us that the entrails are moved with

* e-mail: javierantolino@hotmail.com

Estudio T. Agustiniano. Valladolid 
compassion when the eyes are opened to the suffering of the people and that the mercy entails always an action and it could never remain as a mere feeling.

KEY WORDS: Compassion, parable, prodigal Son and Good Samaritan.

\section{INTRODUCCIÓN}

Las parábolas son quizás el elemento más característico de la doctrina de Jesús consignada en los Evangelios. Y a pesar de los retoques que hubieron de experimentar en el curso de su transmisión, presentan el sello de una personalidad bien definida. Su impacto en la imaginación hizo que se fijaran en la memoria y les procuró un lugar en la tradición. Dodd ${ }^{1}$ asegura que ningún otro género literario del relato evangélico tiene para el lector un tono más evidente de autenticidad.

Las parábolas se presentan como algo nuevo frente al material parabólico del judaísmo ${ }^{2}$. Si comparamos las parábolas de los sinópticos con las de su tiempo, ya sea con las del apóstol Pablo o bien con las parábolas de los rabinos ${ }^{3}$, nos obliga a reconocer un tono de inmediatez y viveza, basado en la experiencia inmediata de la vida real, una peculiaridad estrictamente personal, una maestría desconocida en la composición; tenemos entonces

${ }^{1}$ DodD, H.C., Las Parábolas del Reino, Cristiandad, Madrid 200122, 21. Jeremias, Joachim, Interpretación de las parábolas, Verbo Divino, Estella 19945, 9. Las parábolas son un fragmento de la roca primitiva de la tradición, pues en general las imágenes concretas quedan grabadas en la memoria con más fijeza que los temas abstractos. SNODGRASs, R. Klyne, Stories with Intent. A Comprehensive Guide to the Parables of Jesus, Eerdmans, Grand Rapid, Michigan 2008, 3, está convencido de que las parábolas son el lugar más seguro para acceder a la enseñanza de Jesús.

2 Ramos, F. Felipe, El Reino en Parábolas, Universidad Pontificia de Salamanca, Salamanca 1996, 37-38. En los escritos del NT no se encuentran relatos parabólicos fuera de los evangelios. Por lo que habría que concluir que el modo de hablar en parábolas se remonta al mismo Jesús histórico. BAILEY, E. Kenneth, Finding the Lost. Cultural keys to Luke 15, Concordia Publishing House, Saint Louis 1992, 15-28. En la narración de parábolas, Jesús se basa en el Antiguo Testamento y en la tradición de oriente próximo, donde la metáfora y la comparación eran el foco primario del discurso. Lo opuesto al pensamiento occidental donde se explica algo utilizando conceptos. En cambio, en la mentalidad del próximo oriente se crean conceptos utilizando el símil, la metáfora, la parábola y la acción dramática. La verdad abstracta se hace inteligible con un ejemplo concreto.

3 RAMf́REZ FueYo, Francisco, "Ayer y hoy de las parábolas", en Sal Terrae, 93 (2005), 191. La diferencia entre las parábolas rabínicas, que sobrepasan el millar, y las de Jesús, no está en el género literario, sino en la función con que fueron empleadas. Mientras los rabinos intentan explicar determinados pasajes de la Escritura o de la Tradición, las parábolas de Jesús iluminan la situación concreta que vive. 
que concluir que se trata de una tradición especialmente fiel, estamos en la proximidad inmediata de Jesús 4 .

Aunque los mismos Evangelios dan pie a la interpretación alegórica de las parábolas, es mérito del exegeta protestante Adolf Jülicher en Die Gleichnisreden Jesu (2. vols, 1888 y 1899) haber roto definitivamente con la interpretación alegórica ${ }^{5}$ de las parábolas 6 y estudiarlas en la situación concreta de la vida de Jesús 7 . Ahora bien, Jülicher se queda a medio camino, pues hay que intentar recuperar el sentido original de las parábolas. La exégesis contemporánea se orienta en la línea interpretativa iniciada por Jülicher, que insiste fundamentalmente en el propio impacto de la narración, considerada en y por sí misma.

Es importante tener en cuenta en el estudio de las parábolas de Jesús la diferencia entre la situación de Jesús y la de la Iglesia primitiva. El lugar histórico original, como el de todas las palabras de Jesús, es su actividad en una situación concreta de entonces 8 . Pero luego fueron "vividas" en la Iglesia primitiva, y estamos ante la tarea de recuperar su forma original, en

4 JeREMIAS, Interpretación, 10. DodD, Las Parábolas, 41. Sin resolver el problema de si nos hallamos ante los ipsissima verba de Jesús, hay casos en los que podemos estar seguros de que la aplicación de la parábola se remonta, junto con la parábola misma, a la primera tradición, lo cual nos indica al menos cómo fue entendida por aquellos que se hallaban próximos a la auténtica situación que dio lugar a ella.

5 JeREMIAS, Joachim, Las parábolas de Jesús, Verbo Divino, Estella 19764 ${ }^{4}$ 109. Después de un exhaustivo estudio concluye que el conjunto de las parábolas estaba originalmente libre de interpretaciones alegóricas como en la materia propia de Lucas y el Evangelio de Tomas.

${ }^{6}$ Jülicher distingue entre símil que no necesita interpretación y la metáfora que precisa interpretación. Según él, las parábolas son similitudes y no alegorías, ya que Jesús hablaba a la gente sencilla y lo hacía de una manera diáfana, evitando cualquier ambigüedad. Raymond E. BROwn, "Parable and Allegory Reconsidered", Novum Testamentum 5 (1962) 37. Jülicher, a pesar de sus muchas exageraciones prestó un buen servicio a la exégesis. El método patrístico de tratar las parábolas alegóricamente tuvo un propósito: dado que la Escritura era el catecismo básico de la Iglesia, toda la teología tenía que encontrarse en la Escritura. El rechazo total de Jülicher a la alegoría es simplificado, pues en la mente semita no hay distinción entre parábola y alegoría.

7 JEREMIAS, Interpretación, 14. Las parábolas no son obras de arte, no quieren tampoco inculcar principios generales, sino que cada una de ellas fue pronunciada en una situación concreta de la vida de Jesús, en una coyuntura única, a menudo imprevista.

${ }^{8}$ SCHILlington, V. George, "Engaging with the Parables", en Jesus and his Parables. Interpreting the Parables of Jesus Today, ed. V. George SHILLINGTON, T \& T CLARK, Edinburg 1997, 7-8. Jesús vivió y llevó a cabo su ministerio en la baja Galilea en el mundo religioso judío, social y político del segundo Templo en Palestina, éste es el primer contexto para entender las parábolas que pronunció. TUCKER, T. Jeffrey, Example Stories. Perspectives of Four Parables in the Gospel of Luke (=JSNTS 162), Sheffield Academic Press, Sheffield 1998, 32-35. Las parábolas del Jesús histórico deben ser comprendidas e interpretadas a la luz de su propio contexto cultural, "el contexto original judío". En 
tanto cuanto podemos 9 . Las parábolas se utilizaron al menos dos veces, una por Jesús y otra por los evangelistas. Y nosotros al leerlas tenemos que intentar comprender tanto la intención de Jesús como la intención de los evangelistas. Debemos insistir en el contexto particular de Jesús y no tanto en otros contextos, si realmente queremos escuchar la voz de Jesús. Si las situamos en contextos elegidos por nosotros, entonces estamos alterando la intención comunicativa de Jesús ${ }^{10}$.

En su forma más sencilla la parábola es una metáfora o comparación tomada de la naturaleza o de la vida diaria que atrae al oyente por su viveza o singularidad y deja la mente con ciertas dudas sobre su aplicación exacta, de modo que estimula a una reflexión activa11. En las parábolas de los Evangelios todo está de acuerdo con la naturaleza y la vida. Los procesos de la naturaleza son objeto de una observación y descripción minuciosa; las acciones de los personajes que intervienen en los relatos son adecuadas a la situación. Este realismo de las parábolas de Jesús explica la afinidad interna entre el orden natural y el espiritual, o dicho en términos de las mismas parábolas: el reino de Dios es intrínsecamente semejante a los procesos de la naturaleza y de la vida diaria de los hombres ${ }^{12}$. Las parábolas son la expresión natural de la mente que descubre la verdad en descripciones concretas, en vez de concebirla en abstracciones.

Frente a la comunicación directa que se dirige al oyente sobre un tema que se encuentra a mano, las parábolas usan la comunicación indirecta con el oyente para conocer la verdad. Las parábolas utilizan las metáfo-

general, hay acuerdo en que el uso que hizo Jülicher de la Retórica aristotélica es inadecuado. Pues Jesús no vivió en un ambiente de habla griega, por eso hay que buscar los antecedentes en los profetas del AT y los padres judíos, a la luz de su lengua original. Ahora bien, algunas parábolas del Evangelio de Lucas implican un contexto cultural dife-

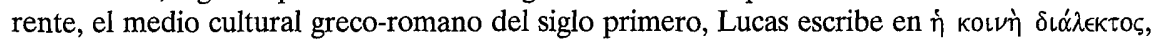
pues se dirige a una audiencia de habla griega y su discurso está impregnado de la tradición retórica propia del período helenístico.

9 JEREMIAS, Interpretación, 82. JEREMIAS, Las parábolas, 141-142. Álvarez Frías, Emilio, "Las parábolas: origen, redacción y mensaje", en Biblia y Fe, 86 (2003), 172-173. Hemos de tener en cuenta también que antes de que fueran escritas fueron vividas por la Iglesia primitiva, que las enseña en la comunidad, las agrupa según objetivos, las sitúa en un nuevo marco concreto y las modifica de acuerdo con la necesidad del momento. También hemos de tener presente, que habiendo sido pronunciadas por Jesús en arameo, fueron traducidas al griego, dando lugar a inevitables modificaciones de sentido al ajustarse al nuevo idioma y a la comprensión de las comunidades gentiles que se hallaban inmersas en condiciones de vida helenista, incluso con costumbres romanas saliendo del ámbito palestino en el que fueron pronunciadas.

10 SNODGRASs, Stories, 26.

11 DoDD, Las parábolas, 27.

12 DoDd, Las parábolas, 32-33. 
ras y las comparaciones, son historietas que tienen dos niveles de significado: el que se muestra en la fábula y el nivel de verdad, en el que la realidad es representada. El objetivo último de la parábola es despertar el pensamiento, estimular la conciencia y llamar a la acción. Las parábolas de Jesús son historietas con intención de transmitir el mensaje de Dios y coadyuvan a comprender el mensaje del reino de Dios. Las parábolas bíblicas revelan lo que Dios es y cómo actúa, y muestran también qué es la humanidad y lo que la humanidad puede y debe llegar a ser. Las parábolas no son meramente informativas. Al igual que los profetas anteriores a él, Jesús pronunció parábolas para provocar una reflexión y estimular una respuesta en relación con Dios. Las parábolas generalmente implican a los oyentes, inducen a la reflexión y promueven la acción. Las parábolas más que transmitir una información intentan convencer y persuadir ${ }^{13}$.

No todas las parábolas son iguales, podemos distinguir diferentes clases de parábolas. Las clasificaciones son nuestras, no de Jesús o de los evangelistas. La palabra griega $\pi \alpha \rho \alpha \beta \jmath \lambda \eta ́$ y la hebrea mashal que corresponde al término griego tienen un significado más amplio y cubren más variedad de formas en los evangelios que la palabra española "parábola". En los estudios bíblicos, la palabra "parábola" tiene al menos tres usos diferentes. Primero, puede usarse como algún dicho comparativo intentando estimular el pensamiento. Se usa como proverbio, acertijo, comparación, contraste, alegoría. Segundo, "parábola" puede usarse en un sentido más restringido para referirse a cualquier analogía, una definición que excluiría proverbios, acertijos o formas no narrativas. Tercero, incluso en un sentido más restrictivo que deriva de la obra de Jülicher que distingue parábolas de similitudes, cuentos y alegorías. Así mientras que similitud, historieta ejemplar y alegoría son todas parábolas bajo la primera definición, en cambio no lo serían bajo este tercer modo más restrictivo de definición. Hay un debate considerable sobre si la alegoría y la historieta ejemplar ${ }^{14}$ son categorías legítimas y sobre cómo caracterizar el símil, y si los símiles y las parábolas se pueden distinguir siempre ${ }^{15}$.

La parábola puede tener un significado literal y también un significado metafórico, en este último caso, la parábola se puede llamar alego-

${ }^{13}$ SNODGRASs, Stories, 8-9.

14 TUCKER, Example Stories, 396-418, ofrece un estudio detallado de las 4 parábolas consideradas como historietas ejemplares en el Evangelio de Lucas y concluye que es una clasificación ociosa pues no hay características comunes a las cuatro; por lo que no conviene mantener esta clasificación aunque corresponda al legado de Jülicher. La distinción entre parábola e historieta ejemplar es superflua por lo que la categoría llamada "example story" es vacía y debe abandonarse.

${ }^{15}$ SNODGRASS, Stories, 9-10. 
ría16. Esto se aprecia en muchas parábolas, por ejemplo la parábola del sembrador, que se refiere a algo que tiene que ver con el reino de Dios, y no con el sentido literal de la siembra, o lo mismo que la parábola del hijo pródigo, pues se refiere a algo más que un hijo que vuelve a la casa del padre. La alegoría es un artificio retórico que imprime al texto una dimensión simbólica. Algunas de las parábolas de Jesús sufrieron una transformación y fueron interpretadas en un sentido alegórico y acomodándolas a su situación y problemática. Por eso ante nosotros aparecen como alegorías y precisan una interpretación. En general, se puede decir que las parábolas tal como han llegado a nosotros son más alegóricas de lo que normalmente se reconoce, aunque no lo sean en una lectura superficial. En otras palabras, los detalles de una parábola tienen significado dentro de la historieta, pero algunos de estos apuntan hacia realidades más altas ${ }^{17}$.

Un número amplio de investigadores consideran las parábolas de Jesús como alegorías ${ }^{18}$ o al menos que tienen características alegóricas que apuntan a realidades más allá de ellas mismas, por eso las parábolas necesitan ser interpretadas. De ahí que algunos tomen la alegoría como una clase de parábolas, aunque sea una clasificación confusa. Otros investigadores argumentan que la alegoría no es un tipo de parábola en absoluto, sino un modo de pensar. Snodgrass ${ }^{19}$ no considera la alegoría como una variedad de parábola, pero reconoce ciertas características alegóricas en las parábolas.

Podemos concluir diciendo que Jesús no compuso alegorías pues era un lenguaje demasiado complicado para los campesinos de Galilea. Cuenta parábolas que sorprenden por su frescura, carácter sencillo, vivo y penetrante. Jesús no hace explicaciones minuciosas de la ley como los escribas, sino que sus parábolas conmueven y hacen pensar; tocan el corazón e invitan a abrirse a Dios y a su Reino. Su mensaje está ahí, abierto a quien lo quiera escuchar ${ }^{20}$. Pero algunas de estas parábolas fueron interpretadas y adquirieron un sentido alegórico que es el que nos ha llegado a nosotros en

16 Ratzinger, Joseph - Benedicto XVI, Jesús de Nazaret. Primera Parte: Desde el Bautismo a la Transfiguración, La esfera de los libros, Madrid 2007, 225. Aunque la distinción entre parábolas y alegorías está justificada, la separación radical entre ambas no tiene fundamento ni en el plano histórico ni en el textual.

17 Greg W. Forbes, The God of Old. The Role of the Lukan Parables in the Purpose of the Luke's Gospel (=JSNTS 198), Sheffield Academic Press, Sheffield 2000, 28-33.

18 FORBES, The God, 35-51.

19 SNODGRASs, Stories, 16-17.

20 RATZinger, Jesús de Nazaret, 229-234. De todos modos, no todo es tan sencillo,

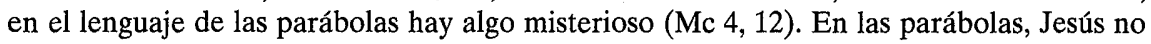
es solo el sembrador que siembra la semilla de la palabra de Dios, sino que es semilla que 
los relatos evangélicos. Por lo que si Jesús no convirtió las parábolas en alegorías, lo que tenemos que buscar es la intención de cada parábola y el propósito por lo que fue pronunciada.

\section{LAS PARÁBOLAS DEL REINO}

El tema común de la teología y la exégesis es la afirmación de que el reino de Dios es el centro de la predicación de Jesús ${ }^{21}$ y la pasión que animó toda su vida. Esto quiere decir que el reino de Dios concentra toda la predicación de Jesús. Y no sólo su predicación, también su actividad. El reino de Dios resume la misión de Jesús. Es la clave interpretativa para entender su mensaje y encierra toda su pretensión pública.

El concepto del reino de Dios no puede ser difícil de comprender pues Jesús se dirige a gente sencilla. El reino de Dios más que a un lugar se refiere a Dios, al poder, reinado y soberanía de Dios. Su modo de hablar mediante las parábolas no son más que perífrasis explicativas del misterio del reino.

Jesús no se cansó de inculcar con imágenes siempre nuevas las ideas centrales de su mensaje, y podemos decir que en las parábolas aparece una síntesis completa del mensaje de Jesús ${ }^{22}$. Todas las parábolas del Evangelio son apologías de la Buena Nueva. La predicación de la Buena Nueva a los pecadores la realizó Jesús de diversos modos: dando el perdón, invitando a los pecadores a la mesa, llamándoles a su seguimiento. Dios es así, tan bueno con los pobres, tan lleno de alegría por encontrar lo perdido, tan lleno de amor paterno con el hijo degradado, tan clemente con los desesperados, los abandonados, los que padecen necesidad, etc 23 .

La mayor parte de estas acciones de Jesús proclaman la llegada del tiempo de la salvación: las acciones parabólicas de Jesús son predicación. Muestran que Jesús no sólo ha anunciado el mensaje de las parábolas, sino que lo vivió y lo encarnó en su persona. Jesús no proclama solamente el mensaje del reino de Dios, él es al mismo tiempo ese mensaje. Todas las parábolas están llenas del "misterio del reino de Dios", a saber, de la certe-

cae en tierra para morir y dar fruto. Por lo tanto las parábolas son expresión del carácter oculto de Dios en este mundo. Así pues, en las parábolas se manifiesta la esencia misma del mensaje de Jesús, el misterio de la cruz.

21 Aguirre, Rafael, La mesa compartida. Estudios del NT desde las ciencias sociales (=PT 77), Sal Terrae, Santander 1994, 135.

22 JEREMIAS, Interpretación, 85.

23 JEREMIAS, Interpretación, 109-110. 
za de que ha comenzado el tiempo de la salvación. Por lo que las fuerzas del mal tienen que ceder, el médico viene a los enfermos, los leprosos quedan limpios, la deuda se perdona, etc 24 .

La expresión Reino de Dios es una afirmación concluyente de la soberanía divina contra el mal existente en el mundo. En el ministerio de Jesús, el poder divino actúa contra el mal. Según Dodd25, la declaración de que el Reino de Dios ya ha llegado aparece en la llamada "escatología realizada", es decir, en el impacto producido sobre este mundo por los "poderes del mundo futuro" en una serie de hechos inéditos e irrepetibles que actúan en el presente. Con la llegada de Jesús, el Reino ha irrumpido de manera definitiva en la historia.

La afirmación "salvación de Dios" desvela espontáneamente lo mismo que exteriorizaba Jesús al mostrar el dominio y el favor de Dios. Cuando Jesús habla del Reino de Dios está hablando de la salvación de Dios, de su poder salvífico, de su intervención favorable. Jesús pone en primer lugar la salvación, la "buena noticia", el Evangelio, el año de gracia que ignora el "día de venganza". Esta es la novedad de Jesús frente a los antiguos profetas y Juan el Bautista.

Cuando uno ha experimentado el sobreabundante amor de Dios, su cariño desmedido, no puede dejar de sentirse transformado y transportado por él. La absoluta cercanía de Dios, en su benevolencia, se sobrepone a cualquier otra cosa, se hace incontenible, mueve a obrar conforme a ella, o a dejar que ella actúe en cada uno. Es lo que la teología entiende bajo el concepto de gracia: don, regalo favorable de Dios, que es eficaz por sí mismo ${ }^{26}$.

El Evangelio, buena noticia de la salvación, y el Reino designan está misma acción salvífica de Dios. En Jesucristo se hace presente esta salvación de Dios, el Reino de Dios. El Evangelio y el Reino simbolizan un nuevo modo de vida, la convicción profunda de que el mal y la injusticia no tienen la última palabra, sino que es Dios quien reina, el soberano de nuestro mundo, donde triunfa el bien y la vida.

24 JEREMIAS, Interpretación, 168-169.

25 DoDD, Las parábolas, 68. DoDD, Las parábolas, 99. "La declaración de que el Reino de Dios ha llegado rompe, de todos modos, con el viejo esquema escatológico y abre paso a un nuevo tipo de ideas. La doctrina de Jesús sobre la naturaleza de Dios y su actitud para con los hombres -su inmensa bondad y beneficencia hacia todas sus criaturas, su ilimitado perdón, su deseo de buscar y salvar lo perdido- lleva necesariamente a una nueva visión de lo que significa la manifestación de la justicia de Dios y la condenación del pecado."

${ }^{26}$ MARCos, Tomás, "Semilla del Reino. Sobre la continuidad entre el Reino de Dios y la Iglesia", en Estudio Agustiniano, 30 (1995), 66. 
Este Reino y soberanía de Dios ${ }^{27}$ son una realidad misteriosa, muchas de las parábolas de Jesús nos acercan al misterio del Reino de Dios, a la misma vida divina. Esta bienaventuranza o salvación que se anuncia es buena nueva, buena noticia, Evangelio. Este modo característico del hablar de Jesús, las parábolas, son en general escenificaciones verbales para describir, de algún modo, rasgos del reino (Mc 4,30).

El material parabólico fue el lenguaje clave de Jesús en su proclamación del acontecimiento del reino de Dios, porque sólo en ese lenguaje poético de imágenes y comparaciones se podía hablar de ese acontecimiento maravilloso, indefinible por conceptos fijos y categorías. Lo que hacen las parábolas es narrar imaginativamente lo que sucede en ese acontecer sorprendente del reino de $\operatorname{Dios}^{28}$.

Dios se ofrece al hombre como rey o, dicho de otro modo, el reino de los cielos es un don de Dios (Lc 12,32), que debe ser aceptado por el hombre. El cumplimiento de la voluntad divina, la observancia de la ley antigua y nueva, es la única garantía para que el don de Dios llegue a sus destinatarios (Lc 6,31). La aceptación de la oferta divina requiere a veces un esfuerzo heroico (Mt 10,34-36; Mc 9, 47). La decisión por el reino es urgente, mañana puede ser tarde. Nunca se dice que el Reino de Dios puede ser conquistado por el propio esfuerzo o adquirido, aunque sea a un alto precio ${ }^{29}$.

El discurso parabólico de Jesús es original, pues a diferencia de las parábolas rabínicas, Jesús es el protagonista, en ellas se ve implicado directamente como el revelador de Dios. En sus parábolas habla de Dios y de su Reino, de la presencia de Dios y de su poder transformante. Posteriormente la confesión de fe cristiana convertirá a Jesús de Nazaret en parábola viviente de Dios, el símbolo vivo o la "imagen visible del Dios invisible" (Col 1,15), que realizó en su vida ${ }^{30}$, lo que nos contó con sus palabras ${ }^{31}$. Las

${ }^{27}$ RAMOs, El Reino, 41. El reino es la intervención definitiva y última de Dios en la historia humana, al mismo tiempo que un nuevo orden moral en el que se cumple perfectamente la voluntad de Dios. 2006, 93

28 VIDAL, Senén, Jesús el Galileo (=Presencia Teológica 148), Sal Terrae, Santander

29 RAMos, El Reino, 42.

30 JeREMfas, Interpretación, 167. Jesús no solamente habló en parábolas, sino que también obró en parábolas. Su acción parabólica más impresionante fue permitir que los despreciados compartiesen su mesa (Lc 19, 5ss) y acogerlos en su casa (Lc 15, 1-2).

31 Ramos, El Reino, 355. Ramos, El Reino, 359. "Jesús como parábola de Dios nos revela su bondad infinita. Así lo demuestra la actitud y actividad de Jesús frente a los marginados de su época: en su relación con los pecadores a los que acoge y perdona; con los publicanos, considerados como impuros y como paganos, a cuya mesa se deja invitar o se auto invita, etc.". 
parábolas de Jesús, sus palabras, enseñanzas y hechos le convirtieron en la parábola de Dios.

Por otra parte, es precisamente en las parábolas donde la enseñanza de Jesús emerge de manera nítida. Es verdad que algunos aspectos de las enseñanzas de Jesús no aparecen en las parábolas. Éstas no hacen referencia a la observancia del sábado, a las leyes culticas, milagros, exorcismos, la cruz o la resurrección., etc. Las parábolas de Jesús no revelan la totalidad de la teología cristiana en absoluto ${ }^{32}$. Sin la cruz y la resurrección, la teología cristiana no existiría. Sin embargo, las parábolas proporcionan material para un convincente retrato sobre las enseñanzas de Jesús sobre el Reino, su comprensión de Dios y la clase de vida que debían llevar sus discípulos, ya vivan en el siglo primero o en el veintiuno ${ }^{33}$.

\section{LAS PARÁBOLAS DE LUCAS}

Aquí vamos a estudiar dos parábolas, tal vez las más conocidas entre todas, se encuentran exclusivamente en Lucas y podemos llamar emblemáticas. Son la parábola del padre y los dos hijos perdidos, tradicionalmente conocida como la del Hijo Pródigo, y la del Buen Samaritano. He elegido estas parábolas pues en ellas se aprecia, de manera diáfana, la misericordia entrañable, del padre para con el hijo que vuelve a casa y del samaritano frente al hombre caído junto al camino. Con ello quiero señalar que la vida cristiana vive esta doble dimensión, primero, descubrir el amor de Dios que se compadece de nosotros y, segundo, nuestra ternura y compasión hacia los otros. En el fondo, es poner en práctica la afirmación lucana: "Sed compasivos como vuestro padre del cielo es compasivo" (Lc 6, 36), que resume lo esencial del mensaje cristiano.

Si antes he intentado ver el mensaje central de las parábolas en su conjunto, ahora, antes de estudiar las dos parábolas en concreto, voy a dilucidar cuál es el mensaje o el objetivo de las parábolas dentro del Evangelio de Lucas.

Primero, hemos de decir que Lucas es el evangelista que más parábolas emplea, incluso es el material más amplio en su Evangelio, el 52\% de éste corresponde a las parábolas y también Lućas es quien presenta más parábolas originales, al menos tiene nueve propias y todas ellas se encuen-

32 SNODGRass, Stories, 360. El problema es que nosotros queremos encontrar en cada parábola toda la teología, cuandọ lo que en realidad pretenden es hacernos pensar y actuar.

33 SNODGRASs, Stories, 31. 
tran en el camino de Jesús hacia Jerusalén (capítulos 10 al 20). El propósito del Evangelio de Lucas, en general, es el de insistir en el cumplimiento de las promesas que Dios ha hecho a su pueblo. Veremos como también las parábolas se acomodan a este mismo objetivo de su Evangelio.

Hemos de decir que las parábolas exclusivas de Lucas, al contrario que las parábolas comunes que tiene con otros sinópticos que podemos llamar parábolas del Reino, tienen un carácter personal y se convierten en una llamada a actuar de una determinada manera, de ahí la popularidad de estos textos que se han convertido en modelos que ilustran el comportamiento humano y cristiano ${ }^{34}$. Se puede decir que la fundamental preocupación de Lucas es el comportamiento moral de la comunidad cristiana. Y si comparamos a Lucas con los otros sinópticos, él es quien menos hace referencia al Reino. Las características de las parábolas de Lucas son las más fáciles de identificar. Lucas muestra preferencia por el soliloquio, por parábolas que comienzan "un cierto hombre" o la expresión "quien de vosotros".

Las parábolas específicas lucanas reflejan la situación de la primitiva iglesia que busca su identidad frente al judaísmo, más que la situación histórica del tiempo de Jesús. Estas parábolas no se encuentran en la fuente $Q$, por lo que serían creaciones libres lucanas donde se subraya su habilidad artística y reflejan y están en armonía con la orientación teológica de todo el Evangelio. Esto mismo podemos afirmar de las parábolas del Buen Samaritano y del Hijo Pródigo, si bien esta última, aunque sea una creación lucana o procede de sus fuentes propias, está en relación con la parábola de la oveja perdida que se encuentra en (Mateo 18,12-14), en el Evangelio de Tomás y en la fuente $Q$. Por lo que aunque la parábola del Hijo pródigo sea una creación lucana, tiene su fundamento en una narración que se puede remitir, de algún modo, al Jesús histórico.

Lucas hace una variada presentación de la imagen y del modo de ser de Dios: su cuidado y su amor, su misericordia y su gracia, y Dios como juez soberano. Por ejemplo, el buen samaritano refleja el amor de Dios curando las heridas de los afligidos. Sin embargo, la parábola enseña a una audiencia etnocéntrica que su comprensión de Dios tiene que cambiar, pues el amor y el cuidado de Dios no pueden limitarse a los ideales culturales de un determinado grupo social. La parábola del hijo perdido refleja

${ }^{34}$ ForBes, The God, 17. SNODGRASs, Stories, 18 y 20. Las parábolas intentar cambiar el comportamiento y crear discípulos. Su principal propósito es provocar una respuesta en los oyentes. Las parábolas buscan la conversión pero hablando de Dios y su reino, la nueva realidad que Dios quiere establecer sobre la tierra. 
el amor de Dios en el padre que trata a los dos hijos con igual respeto y paciencia. Al mismo tiempo, encontramos la imagen de un Dios que no refuerza su autoridad, dando al hijo menor la libertad de rebelarse. Dios desea la comunidad perfecta, pero esto será alcanzado por el camino de la compasión y la alegría, y no por la fuerza ${ }^{35}$. La imagen de Dios que se alegra por el hijo perdido y encontrado es única entre las parábolas de Jesús.

Primeramente, Lucas por medio de las parábolas quiere demostrar que de ellas fluye el comportamiento cristiano, que imita el modo de ser de Dios. Bien en una situación de oposición por parte de los judíos, o simplemente en una situación en que la iglesia gentil buscaba clarificar su posición en relación con el Judaísmo, las parábolas muestran que el Cristianismo es el cumplimiento de la esperanza judía. La actuación de Jesús y la presentación del carácter y naturaleza de Dios en las parábolas, se sitúan en continuidad con el Dios del Antiguo Testamento. Esta descripción contrasta con algunos aspectos clave de la comprensión judía de Dios. De este modo, la descripción lucana de la naturaleza de Dios en las parábolas sirve a una función apologética y demuestra a sus lectores esa continuidad con relación a una comprensión exacta de Dios que se encuentra en el Antiguo Testamento de la cristiandad, y no en el Antiguo Testamento del judaís$\mathrm{mo}^{36}$.

Aunque es imposible conocer con seguridad los destinatarios del evangelio de Lucas, la deducción más plausible, desde la evidencia interna, sugiere que el lector es un gentil que está muy relacionado con la oración del Dios de Israel en la sinagoga, quien tiene un gran aprecio de la àutoridad y el contenido del Antiguo Testamento, y que tiene algún conocimiento de la fe cristiana. Tal vez Lucas, aunque menciona a Teófilo, se dirige a un grupo más amplio, a los llamados temerosos de Dios. Aunque haya diversos propósitos secundarios bajo la obra lucana, su intención principal parece ser evangelizadora. Si es así, las parábolas de Lucas, en su descripción del Dios del Antiguo Testamento, no son solamente usadas para el discipulado y propósitos apologéticos, sino que forman también una parte integral de la proclamación evangélica lucana ${ }^{37}$.

$\mathrm{El}$ aspecto distintivo de las parábolas de Lucas radica, comparado con las parábolas sinópticas del reino, en que presentan una variada y desarrollada imagen de Dios que es cariñoso y bondadoso con todas las personas, compasivo y misericordioso, e incluso juez soberano. Ninguno de estos ras-

\footnotetext{
35 FORBES, The God, 252-253.

${ }^{36}$ FORBES, The God, 318-319.

${ }^{37}$ ForBes, The God, 326-327.
} 
gos del carácter divino (quizás con la excepción del Dios que se alegra por el retorno del hijo extraviado) es nuevo en Jesús, sino que es una parte integral del retrato de Dios en el Antiguo Testamento. Así, las parábolas incrementan el uso lucano del Antiguo Testamento, que es central en el tema de la promesa-cumplimiento, por lo que Lucas manifiesta que Jesús es el cumplimiento legítimo de las esperanzas y promesas del AT. Aunque expresan una continuidad con el modo de ser de Dios del AT, las parábolas también expresan una cierta discontinuidad con algunas visiones contemporáneas judías de Dios. En particular, las actitudes hacia los no judíos, una preocupación por los grupos marginados y pecadores, la elección como una cancelación del juicio, riqueza como un signo de la bendición de Dios y, posiblemente, la accesibilidad de Dios en la oración. La preocupación lucana es demostrar que en el Cristianismo se ha cumplido la esperanza judía de la salvación ${ }^{38}$.

\section{LA PARÁBOLA DEL HIJO PRÓDIGO39}

\section{En el contexto del capítulo $15^{40}$}

La parábola que centra nuestra atención se encuentra en el capítulo 15 del Evangelio de Lucas junto con otras dos parábolas, la de la oveja per-

38 FORBES, The God, 328-329.

39 BARTOLOMÉ, Juan José, La alegría del padre. Estudio exegético de Lc. 15, Verbo Divino, Estella 2000, 42. El título tradicional, la parábola del hijo pródigo, no hace justicia a su contenido temático ni a la intención del narrador. CONTRERAS Molina, Francisco, Un padre tenía dos hijos (Lc 15, 11-32), Verbo Divino, Estella 1999, 27. Por eso, se han propuesto otros títulos alternativos: "El hijo perdido y el hijo fiel", "La parábola de los dos hermanos", "la parábola del amor del padre" (Jeremias), "la parábola del padre misericordioso", "la parábola del padre compasivo y los dos hijos perdidos", "la parábola del padre pródigo", "Un padre tenía dos hijos", etc. MARSHALl, I. Howard, The Gospel of Luke. A Commentary on the Greek Text, Exeter the Paternoster Press, Graville 1978, 604. Entre todas las parábolas tal vez sea esta la más fácil de interpretar en un sentido amplio, pero es también la más abierta a múltiples interpretaciones, depende donde pongamos la atención. Así por ejemplo WrigHT, T. N, Jesus and the Victory of God, Vol II, Fortress Press, Minneapolis 1996, 126-127, aplica la parábola al pueblo de Israel, al exilio y a la restauración. Israel es llevado deportado a un país pagano, y allí viven en el exilio esclavizados, finalmente vuelve a su tierra. La parábola del hijo pródigo explicaría la experiencia del pueblo de Israel del exilio y la restauración. Israel es llevado al exilio por su propia torpeza y desobediencia; ahora vuelve a su tierra por la generosidad y benevolencia de Dios.

40 Bartolomé, La alegría, 73. Es típico del relato parabólico de Lc 15 el que tan sólo la primera parábola sea conocida por la tradición evangélica. En consecuencia, todo el material restante (Lc 15, 1-3.8-32) se ha atribuido a fuentes propias del evangelista o a 
dida y la de la dracma perdida. Pocos textos han gozado de tanto aprecio y valoración. Se ha llegado a decir que Lc 15, con sus tres parábolas sobre la salvación de lo que estaba perdido es el corazón del Evangelio de Lucas ${ }^{41}$ y constituye un "evangelio en el evangelio" o el núcleo vivo del corazón de todo el evangelio.

No obstante, aunque la parábola Lc 15, 11-32, probablemente sea la más apreciada ${ }^{42}$ y comentada en la historia del Cristianismo, es la peor entendida. Ya el mismo título, parábola del hijo pródigo, con el que tradicionalmente es conocida, da prueba de un inveterado error de comprensión. La parábola no habla sólo de la conversión del malo, ni cuenta únicamente el retorno a casa del pecador; pide también la conversión del bueno, invitándole a entrar en casa. En ello, en que el hermano que nunca abandonó el hogar reconozca como hermano al hijo recuperado por su padre, consiste -ni más, ni menos- la alegría de Dios ${ }^{43}$.

Las dos primeras parábolas están construidas con una notable simetría, se pueden llamar gemelas. En ambas, el centro de interés no radica en el objeto perdido y hallado, sino en la persona que lo pierde y que reencuentra la alegría al recuperarlo44.

Los tres personajes principales en las parábolas quedan calificados por tener un rebaño, un capital, una familia, por su pérdida parcial y limitada en el tiempo y la recuperación posterior que les produce alegría ${ }^{45}$. La alegría común es el tema principal que une las tres parábolas de este capítulo.

En general se acepta la unidad interna del capítulo 15: una breve narración (1-2) abre un único y largo discurso (3-32). Las dos primeras

su labor personal de redacción. SNODGRASs, Stories, 95. Los cuatro componentes dominantes del Evangelio de Jesús son la celebración, la compasión, la restauración de Israel y el presente y futuro del Reino de Dios. Las parábolas del capítulo 15 muestran la celebración y la compasión. Los otros dos temas están implícitos. En consecuencia, este capítulo es la más vigorosa descripción que existe de Dios buscando a los pecadores y alegrándose por su retorno.

41 Forbes, The God, 109.

42 RAMOS, El reino, 268, la considera la perla de las parábolas, el resumen más vivo y acabado del Evangelio. SANZ JimÉnEz Rico, Enrique, Profetas de misericordia. Trasmisores de una palabra, San Pablo, Madrid 2007, 187-188, certifica que es una parábola que hace del amor de Dios todo un acontecimiento y que toca el corazón del tercer evangelio, y expresa cómo ama Dios.

43 BARTOLOMÉ, La alegría, 7.

44 BARTOLOMÉ, La alegría, 16.

45 Evans, C. F., Saint Luke, SCM and Trinity Press International, London 1990, 582. Las tres parábolas están unidas por el tema común de la alegría de recuperar lo perdido. ForBES, The God, 117. La alegría es un motivo típicamente lucano $(1,14,47 ; 2,10 ; 10,20-21$; $13,7 ; 15,10 ; 24,52 ;$ Heh 2,46$)$, que no solamente aparece en las tres parábolas del capítulo 15 , sino que incluso se menciona tres veces en la parábola de la oveja perdida. 
parábolas (4-7.8-11) simétricas en su estructura y coincidentes en su significado están simplemente unidas por una copulativa. La tercera (11b-32), ligada a las anteriores explícitamente (11a), retoma el contenido de ellas en una disposición binaria (15-24.15-32): a la doble parábola inicial corresponden los dos cuadros de la tercera, que describen la relación problemática entre sus personajes. Aceptada esta composición unitaria de Lc 15, parece legítimo adelantar una doble consecuencia que podrá guiar el esfuerzo de comprensión. En primer lugar, dada la unidad formal existente, sus partes integrantes no han de ser entendidas de forma aislada: la relación que media entre ellas obliga a tenerlas en cuenta a todas, cuando se trate de interpretar cada una en particular. Ello significa que las tres parábolas complementan e iluminan el mensaje de cada una; implica, por otro lado, que el marco redaccional aporta el contexto en el que han de entenderse. Siendo una ley de la narrativa popular el situar al final el dato clave para la comprensión global del relato, será lógico apoyarse en el último cuadro narrativo para buscar el mensaje básico de Lc 15. La defensa de la alegría 46 que proporciona a Dios el perdón no sólo es afirmada en (7.10.24), es, sobre todo, defendida (v. 32). Y de forma paradójica, ya que el relato culmina con el riesgo de perder al que no se había extraviado ${ }^{47}$.

El discurso parabólico de Lc 15, 3-3248 tuvo como motivo una situación conflictiva (Lc 15,1-2), originada en la costumbre que Jesús mantenía de comer con pecadores públicos ${ }^{49}$. El evangelista Lucas ${ }^{50}$ presenta la comida con pecadores como práctica habitual de Jesús, no como un hecho aislado ${ }^{51}$. Si Jesús hubiera rehuido alguna vez la compañía de pecadores

46 Nolland, John, Luke 9: 21-18:32 (=WBC 35b), Word Books, Dallas, TX 1993, 780. La tercera parábola completa el capítulo 15. La "alegría en el cielo" (vv. 7,10) orienta al lector a unirse a la experiencia del padre con el gozo divino. La unidad de las tres parábolas se encuentra en el motivo del arrepentimiento y de la alegría compartida. Los dos personajes de la parábola, el hijo menor y el mayor, hay que relacionarlos, el primero con los publicanos y pecadores y el segundo con los fariseos y escribas.

47 Bartolomé, La alegría, 22-23.

48 Marshall, The Gospel, 597. El discurso parabólico sirve para justificar la actitud de comer con publicanos y pecadores.

49 BARTOLOMÉ, La alegría, 109. La participación de Jesús en comidas con pecadores y publicanos pertenece al núcleo más seguro de la tradición evangélica. Hay suficientes textos en la tradición que avalan semejante praxis.

50 Bovon, François, El Evangelio según san Lucas III: Lc 15, 1-19,27), traducción Alfonso Ortiz García, Sígueme, Salamanca 2002 35, dice que ante todo reflejan la idea teológica de Lucas: mientras que el Jesús histórico aceptaba ser acogido por los pecadores (5, 29-32), él es aquí el que los recibe (v. 2); además, las comidas en común aparecen en segundo término (v. 2); lo que importa es escuchar al Maestro (v. 1).

51 Aguirre, La mesa, 63, afirma que comer con los pecadores no fue para Jesús un acto puntual, sino una costumbre. CONTRERAS, Un padre, 227-230. El comer con los peca- 
públicos, como era habitual entre fariseos ${ }^{52}$, no se hubiera inventado ese marco redaccional. Lucas quiere hacernos ver que entre la actuación de Jesús y la de Dios hay una neta continuidad, describiendo en parábolas el comportamiento divino. Jesús se presenta en el capítulo $15^{53}$ como el portador de una invitación incondicionada, dirigida por igual a justos y a pecadores, que les ofrece la comunidad de vida con Dios, una comunidad que él ya está viviendo.

Pero lo verdaderamente decisivo es que las comidas con personas marginadas eran ya, como acontecimiento concreto, una parábola vivida. Su convivencia con los pecadores fue su primera palabra sobre el Dios que predicaba; con ella no estaba diciendo más, ni tampoco menos de cuanto expresó con su discurso: sus parábolas no fueron nunca sentencias autónomas, verdades universalmente válidas; estaban preanunciadas en su vida y eran la mejor razón de ella ${ }^{54}$. Con Jesús se inicia el tiempo de la alegría de Dios: quien, pecador o no, aceptara al Dios que Jesús predicaba con sus parábolas y representaba con sus gestos, se convertía en compañero de la dicha divina, sea que la motivara o se uniera a su celebración ${ }^{55}$.

La conducta de Jesús, su cordial acogida a los pecadores y su comer juntos (Lc 15,2), no tendría sentido si no se la reconociera como manifestación de la solicitud de Dios por los perdidos: su búsqueda consigue el perdón, la gracia que antecede a la conversión ${ }^{56}$. La identidad operativa entre

dores es un rasgo típico de Jesús; se remonta a su existencia histórica. Dos factores lo hacen completamente original: su total ruptura con el comportamiento de la piedad judía y la imposibilidad de invención por parte de la Iglesia.

${ }_{52}$ Los fariseos eran incapaces de compartir la mesa con aquellos que eran considerados pecadores (Ex. 18,1).

53 BARTOLOMÉ, La alegría, 115. Lc 15 es tanto una declaración del pensamiento de Jesús sobre Dios, una especie de resumen de su teología personal, como la del pensamiento de Dios sobre el pecador, una especie de compendio de soteriología divina. CoNTRERAS, Un padre, 210. Jesús se presenta como la imagen del padre que busca lo perdido.

54 BARTOLOMÉ, La alegría, 119.

55 BARTOLOMÉ, La alegría, 121. En Lucas 15 Jesús proclamó un Dios para los perdidos. Aquí reside la paradoja, seguramente la mayor de todo el discurso: no en que Dios sea misericordioso aceptando pecadores sino en que Dios no obligue a los justos a que le acepten, simplemente les invita a ello. El padre no obliga al hijo pequeño a quedarse, ni a regresar, lo mismo que no impone la fiesta al mayor; pero un padre que no se impone, es un padre que puede perderse: si fomenta la libertad filial, también facilita el rechazo fraterno. Quien no acepta la misericordia de Dios para con los otros, los peores, pierde la oportunidad de convertir en propia la alegría de Dios; más aún, pierde a Dios, no sólo su alegría. JeREMIAs, Interpretación, 102. Así es Dios. Quiere la salvación de los perdidos, pues le pertenecen; le ha dolido su extravío y se alegra de su retorno al redil. Jesús habla de la "alegría soteriológica" de Dios, de la alegría de perdonar.

56 CONTRERAs, Un padre, 248. En los profetas aparecía esta misma idea, Dios perdona antes de que el pueblo se convierta, el perdón antecede a la conversión. San Pablo 
Jesús de Nazaret y el Dios de Israel, que se reflejaba en la comunidad de mesa con pecadores, pudo aparecer como una insolente provocación, como una actuación anárquica, social y religiosa, a los ojos de sus contemporáneos; para Jesús, en cambio, era expresión y confirmación de que el reino había llegado y con él, la alegría, común y sin fronteras era una realidad posible: comiendo con los pecadores, Jesús practicaba el reino que estaba proclamando. Jesús no solamente predicaba el Evangelio, sino que vivía y practicaba ese mismo Evangelio 57.

Lo que Jesús pretende decir con sus parábolas es semejante a lo que decía en su actuación comiendo con los pecadores. Las afirmaciones centrales de su discurso (Lc 15, 7.10.24.32) no fueron más escandalosas que su provocadora actuación (Lc. 15, 1-2). Es decir, Jesús afirma con solemnidad que Dios se alegra por la vuelta de un pecador. De este modo Jesús ha acercado a los publicanos y pecadores el ser más profundo y característico de Dios, que Dios es excesiva y exageradamente misericordioso. El capítulo 15 de Lucas repite y reitera con insistencia que Dios quiere la salvación de todos (el hijo mayor y el menor) y especialmente de los perdidos, y que Jesús habla de dicha misericordia y salvación en su comunión de mesa con publicanos y pecadores ${ }^{58}$.

Podemos afirmar pues que el evangelista en Lc 15 invita a superar cualquier deslizamiento comunitario hacia el exclusivismo religioso que pusiera en peligro la fraternidad sin fronteras que la actuación divina había hecho posible. Del mismo modo que Jesús se apoyó en la actuación de

recalca también la gratuidad y el anticipo de la misericordia divina (Rom 5,8) e idéntico mensaje proclama Juan en su primera carta $\left(1^{\mathrm{a}} \mathrm{Jn} 4,10\right)$. Insistir en la primacía absoluta de la misericordia no quiere decir invalidar la conversión, ni que ésta aparezca como innecesaria. BARTOLOMÉ, La alegría, 117. Lo que resulta inédito e insoportable es que Dios no considere la conversión del pecador como condición previa para su perdón.

57 BARTOlomé, La alegría, 122-123. ConTreras, Un padre, 239. El comportamiento de Jesús de comer con los pecadores se inspiraba en lo que Dios mismo era y hacía; de él recibía su aliento y empuje; y simultáneamente la praxis de Jesús espejaba la conducta divina. Si Dios actuaba así, él también se comportaba de la misma manera. Jesús de Nazaret se presentó en sus comidas con los pecadores desvelando la voluntad de Dios; en él aparecía la encarnación humana de la misericordia divina, que busca con solicitud la gente perdida. En la persona de Jesús, que come con los pecadores, convive la benevolencia del mismo Dios, que construye de esta forma insospechada su reino escatológico. Jesús no era sólo el intérprete que explicaba el Reino, sino también su artífice eficaz. Comiendo con los pecadores mostraba a las claras que el Reino había llegado con su presencia acogedora. En Jesús se hace presente Dios y su Reino.

58 Sanz Giménez-Rico, Profetas, 218-219. Bailey, Finding, 62-63. El padre de la parábola hace exactamente lo que la audiencia está acusando a Jesús: acoger a un pecador (el pródigo) y comer con él. 
Dios, la comunidad lucana se justificaba recordando el comportamiento de su Señor. Continuando la praxis de Jesús, de hacer prójimo y comensales a los alejados de su tiempo, la comunidad creyente se autentificaría como cristiana. Sólo una iglesia abierta a todos podía aspirar a ser el pueblo del Dios de Jesús, sólo así sería capaz de festejar la misericordia, la alegría del perdón 59 .

La intención de la primera parábola es mostrar la alegría que experimenta el pastor que recupera la oveja perdida. Esta alegría sentida necesita ser comunicada; de la comunicación surge la invitación a los más próximos a que la compartan. La alegría del pastor es tan grande, tan expansiva, que debe publicarla e invitar a participar en ella a los que le son más próximos. En lugar del esfuerzo, de búsqueda por parte del pastor, en la aplicación de Jesús resalta la conversión del pecador como motivo de la alegría divina. Aquí no se quiere expresar la relación del pastor con el rebaño, sino sólo y únicamente la alegría por encontrar lo perdido.

Así es Dios, quiere la salvación de los perdidos, pues le pertenecen; sus andares errantes le han dolido y él se alegra del retorno. Esta alegría en el corazón de Dios no la causa el arrepentimiento del pecador sino el reencuentro de Dios con él60. Lo que se nos muestra es que la actitud de Dios no es pasiva esperando que la gente regrese, sino que es Dios quien toma la iniciativa para que la gente vuelva a él, sin fijarse en lo perdida que estaba. Esta parábola muestra la gracia ilimitada de Dios, de forma incuestionable Dios busca y restaura lo perdido. La búsqueda y la alegría son los dos pilares de la parábola ${ }^{61}$. La alegría ${ }^{62}$, la actitud de Dios por recuperar

${ }^{59}$ BARTOLOMÉ, La alegría, 105-108.

60 BARTOLOME, La alegría, 36-37. ConTRERAs, Un padre, 214. La parábola enseña que la oveja perdida no tiene otro título ni mérito sino su propia perdición y el cariño que despierta en su pastor. Los pecadores experimentan que su misma condición de gente perdida y el reconocimiento de su extravío se convierten en el motivo desencadenante de tanta solicitud y alegría, propias de la misericordia de Dios. MARSHALL, The Gospel, 601602. El punto central de la parábola no es el amor manifestado por Dios, sino la alegría que se experimenta en el Reino de Dios por la nueva situación. La parábola se concentra en la alegría de Dios y no en la actitud del pecador.

61 BaIley, Poet, 153-156, señala que en la parábola aparecen cuatro temas fundamentales que hay que entender conjuntamente. Estos son: la alegría del pastor que comparte con la comunidad, a la esforzada búsqueda le sigue la alegría del encuentro, la gracia incondicionada que busca lo perdido, y una nueva comprensión del arrepentimiento.

62 SNODgrass, Stories, 110, indica que se debe poner especialmente atención en la alegría, pues la oración cristiana, a menudo, carece de alegría. El gozo es la característica verdadera del Cristianismo, pues tiene relación con la disposición de Dios que busca y celebra la recuperación de lo perdido. 
lo perdido y la celebración del Reino con sus buenas noticias manifiestan que la promesa de redención de Dios ha comenzado63.

La parábola de la dracma perdida es paralela a la anterior. El encontrar lo perdido64 lleva al reencuentro con la alegría, y se convoca a las vecinas para invitarles a compartirla. Las vecinas y amigas están invitadas a compartir el gozo que experimenta la mujer65 que recupera su capital. La aplicación de la parábola (v. 10) es idéntica a la anterior. Se centra en la alegría de Dios por el retorno del pecador. La alegría de Dios (otra vez la nota de la alegría es una característica del Reino, donde falta la alegría, falta el Reino de Dios) que Jesús predicaba radica en su reencuentro con quienes echaba de menos; es el comportamiento de Dios, su mentalidad, descrita por Jesús, lo que sorprende. En la predicación de Jesús y en su actuación el Reino de Dios estaba llegando, y uno de los rasgos de esa llegada era ese inédito interés por lo "perdido"66. Implícitamente, como la anterior, es una parábola del Reino de Dios, pues en el ministerio de Jesús, Dios redime a su pueblo y cumple la promesa de restaurar Israel. Dios es el buscador diligente, quien toma la iniciativa de recuperar lo que le pertenece. Dios no solamente acepta a los pecadores, sino que les busca impacientemente y el encuentro le lleva a una celebración gozosa. El Reino de Dios viene con gracia ilimitada, incluso para aquellos rechazados por otros ${ }^{67}$.

La presentación que hace Lucas de Jesús pretende actualizar el amor de Dios por los pecadores arrepentidos. La búsqueda de Dios de lo perdido, así como la alegría cuando lo halla, es un acontecimiento concreto en la vida de Jesús, antes de ser contenido de su enseñanza o tema de controversia. Con estas dos parábolas Jesús daba a entender que en la comunidad de mesa con los pecadores estaba aconteciendo la acción salvífica de Dios. Jesús, en su actuación personal, hacía suya la misma acción de Dios. La comunidad de mesa de Jesús con los pecadores no sólo estaba justificada

63 SNODGRASS, Stories, 109.

64 CONTRERAS, Un hombre, 215. El cuidado de la mujer hará posible que la moneda sea encontrada. Es decir, solamente la solicitud de Dios, presente en Jesús, encontrará a los hombres y mujeres perdidos sin remedio.

65 BAILEY, Poet, 158, considera que el utilizar a la mujer como ejemplo de búsqueda requiere una decisión moral, lo mismo que a los pastores en la parábola anterior; pues los pastores y las mujeres eran grupos proscritos en la sociedad.

66 Dodd, Las Parábolas, 147. ConTreras, Un padre, 215-216. En la escena de Zaqueo del Evangelio de Lucas aparece de forma señera la búsqueda de Jesús de un hombre perdido, lo busca y le concede la plena salvación.

${ }^{67}$ SNODGRAss, Stories, 116. 
en la búsqueda divina de cuanto estaba perdido ${ }^{68}$, era, además, un signo eficaz de esa misma preocupación por lograr el encuentro69.

\section{La parábola del padre compasivo y de los dos hijos perdidos ${ }^{70}$}

En el comentario de esta parábola ${ }^{71}$ voy a centrarme en el tema de la misericordia del Padre y la celebración o alegría de la que quiere hacer partícipe también al hermano que se ha quedado en casa.

68 AgUIRre, La mesa, 64-65. En el fondo hay una lucha de dioses: el Dios de la santidad al que se accede separándose de lo profano y de lo impuro, y el Dios de la misericordia, al que se accede en la medida en que se busca la incorporación de los excluidos. Jesús quiere justificarse ante quienes se escandalizan porque su actitud rompe el sistema de pureza, y desea que también los escribas y fariseos, que le critican, participen de su alegría.

69 Bartolomé, La alegría, 40-41. BARTolomé, La alegría, 116. Las comidas de Jesús con pecadores implicaban su completa seguridad acerca de la disposición de Dios al perdón. Esta predisposición divina a la misericordia pertenecía por entero a la imagen divina que el Judaísmo tenía; Jesús, por tanto, no se situaba fuera de la tradición bíblica. Pero la insistencia en la misericordia divina, sin condicionamientos previos, avalaba su comportamiento público, el relieve que daba a la preocupación paterna de Dios por quien se hubiera perdido y su neta afirmación de que el Padre ordena la fiesta común, cuando a Él se retorna - una fiesta que no había ofrecido a los que con él se quedaron-, y propone, además, al recién llegado como hermano; todo ello rompe los límites de ese concepto de Dios del que Jesús, predicador judío, había partido.

70 Contreras, Un padre, 28-29. Podemos decir que nuestra parábola corresponde con la forma de pensar y actuar de Jesús. También podemos admitir que el evangelista Lucas la ha tomado de su fuente propia y la ha reelaborado concienzudamente. EvANS, Saint Luke, 590, entiende esta parábola en continuidad con las anteriores, en el sentido de la pérdida y la alegría del encuentro: "estaba perdido y lo hemos encontrado, estaba muerto y ha vuelto a la vida" (vv. 24 y 32); pero esta comparación es algo artificial, pues el hijo no está perdido y el padre no va en su búsqueda. SNODGRASs, Stories, 134. Las dos primeras parábolas del capítulo se centran en la búsqueda, la alegría y la celebración por el encuentro. Ambas comparan la alegría del encuentro con la alegría que acompaña al arrepentimiento. La tercera parábola desarrolla el tema de la alegría y la fiesta incluso más, pero contrasta la actitud del padre y la del hermano mayor. Este contraste refleja la actitud de Dios hacia los pecadores arrepentidos y el modo de ser de aquellos que rechazan alegrarse y, por el contrario, menosprecian a los pecadores arrepentidos. La parábola presenta el contraste entre la aceptación de los pecadores por parte de Dios y el rechazo por parte de los fariseos. FORBES, The God, 148, insiste en que la parábola sirve, como las dos previas, para darnos una justificación del ministerio de Jesús con los marginados y pecadores. Es Jesús quien con sus acciones demuestra la compasión, el amor paciente y la aceptación incondicional de Dios por lo perdido. Eso significa que el reino de Dios es ahora operativo en las palabras y acciones de Jesús.

71 Holgate, A. David, Prodigality, Liberality and Meanness. The Prodigal Son in Greco-Roman Perspective on Luke 15, 11-32 (=JSNTSS 187), Sheffield Academic Press, Sheffield 1999, hace un estudio de esta parábola en la perspectiva de la cultura greco- 
El hijo menor no disculpa su proceder ni niega su responsabilidad; declara ante si mismo su arrepentimiento ${ }^{72}$, confiesa en su interior el pecado, que después, intentará proclamar abiertamente (Lc 15,21). Este cambio que se realiza en el hijo, se trasluce en la aceptación de haber perdido todo derecho a ser considerado como tal en la casa del padre (v. 19). Acepta como favor ser un siervo en la casa del padre. Es lo máximo a lo que podía aspirar o soñar; no se merecía a su padre.

A continuación el relato se centra en el padre (Lc 15, 20-32), y ya no desaparecerá en toda la parábola, y aunque es una parábola bipartita, el auténtico protagonista es el padre ${ }^{73}$. El padre al verlo ${ }^{74}$ de lejos se conmovió. El verbo $\sigma \pi \lambda \alpha \gamma \chi \nu \nu^{\prime} \zeta o \mu \alpha \iota \epsilon^{\prime} \sigma \pi \lambda \alpha \gamma \chi \nu i \sigma \theta \eta^{75}$, que Lucas utiliza en su material propio dos veces más (Lc 7,13 y 10,33), expresa el núcleo de la historia: el

romana de la época. Holgate argumenta que frente a las virtudes del padre de la compasión y liberalidad, se presentan los vicios de los dos hijos, en el menor el derroche y despilfarro, y la mezquindad del hijo mayor. El padre aparece como la persona virtuosa que domina sus deseos. Los hijos, en cambio, se dejan llevar por deseos desordenados.

72 Algunos comentaristas dicen que realmente no muestra arrepentimiento, sino que la razón por la que decide volver es el hambre, esto es lo que le hace recapacitar. BAYLEY, Poet, 175-177. BAYLey, Finding, 129-133. RohrbaUgH, L. Richard, "A Dysfunctional Family and its Neighbors (Luke 15:11b-32)", en Jesus and his Parables. Interpreting the Parables of Jesus Today, ed. V. George ScHILlIngTON, T \& T CLARK, Edinburg 1997, 155. FoRBES, The God, 136. De todos modos, no hay contradicción entre hambre y arrepentimiento, pues el hambre puede ayudar a recapacitar y facilitar la conversión.

73 FITZMYER, A. Joseph, El Evangelio de san Lucas, v. III. Comentario de los capítulos 9,50 al 19,27. Cristiandad, Madrid 1986. 672-673. Holgate, Prodigality, 67. El personaje más importante es el padre. Lucas concentra la atención en él y sugiere que su comportamiento es un ejemplo positivo para los lectores. Representa el comportamiento estándar desde los que otros comportamientos deben ser juzgados. Lucas subraya dos virtudes en el padre: la liberalidad y la compasión. Los trabajadores y siervos revelan su liberalidad y los hijos evocan su compasión.

$74 \mathrm{El}$ ver es un componente esencial de la compasión, pues la despierta y aviva. Este mismo comportamiento se aprecia al estudiar en los Evangelios la misericordia de Jesús de Nazaret.

75 ConTreras, Un padre, 94-95. Esta palabra expresa los sentimientos profundos del padre. No solamente el verbo en sí mismo requiere nuestra atención; ocupa también un lugar señero en el verso y en la parábola. El centro de la parábola lo detenta el verbo "se conmovió en sus entrañas". MENKEN, M. J. J., "The position of $\sigma \pi \lambda \alpha \gamma \chi \nu i \zeta \epsilon \sigma \theta \alpha \iota$ and $\sigma \pi \lambda \alpha \gamma \gamma \chi v \alpha$ in the Gospel of Luke", en Novum Testamentum 30 (1988), 108. No es tanto la acción del padre sino la compasión entrañable lo que constituye el eje radial de la parábola. Todo el desarrollo posterior no es sino la resultante de su compasión, que dinamiza su

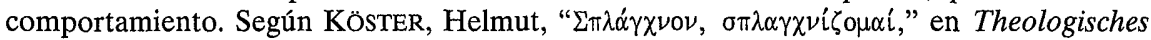
Wörterbuch zum Neuen Testament, VII, 549, en el mundo cultural-religioso griego no se concibe la palabra $\sigma \pi \lambda \alpha^{\prime} \gamma \chi \nu \alpha$ como la sede de la misericordia. Esto sucederá en la revela-

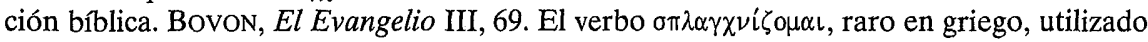
por los LXX y presente en El Testamento de los XII Patriarcas, ha tomado el sentido de "tener piedad", "tener compasión", significado que encontramos también en la litera- 
sentimiento paterno, que llega hasta las entrañas, precede a cualquier declaración de arrepentimiento del hijo ${ }^{76}$. El padre no espera ningún signo de contrición, sino que nos encontramos que un padre se conmueve ante el hijo que había perdido. A la conmoción interior le sigue la actuación pública: el padre corre hacia el hijo, lo abraza nada más encontrarlo y le besa antes de que pronuncie palabra alguna. El padre al correr hace algo no sólo desacostumbrado para un oriental de su edad, parece que reacciona con poca dignidad; pero con enorme ternura y alegría 77 .

El padre devolvió al recién llegado su rango, haciéndole de nuevo hijo a quien sólo pensaba en llegar a ser siervo. El padre hace todo lo posible por reintegrar plenamente a su hijo en la familia. El hijo se había preparado para una fría recepción: su ilusión era llegar a ser asalariado; en vez de la autoridad paterna se encontró con su ternura. Vuelve a ser hijo, gracias al comportamiento del padre: ha sido perdonado antes de

tura cristiana primitiva. CONTRERAS, Un padre, 99-100. Sobre la palabra rehem, útero y regazo materno, el lenguaje bíblico ha desarrollado el plural rahamin (entrañas), el "sitio tierno" alojado en la naturaleza humana, en lo más íntimo de las entrañas de una madre. Desde la significación de vientre de una mujer pasa a expresar las entrañas de una madre; y aún más, el amor de una madre, sin perder nunca la religación con el sustantivo. Pero en la mayoría de los casos, el plural rahamim (en los dos tercios del empleo bíblico) aparece teñido de sentido teológico. Aplicado a Dios, designa sentimientos de misericordia, de ternura, pero siempre arraigados en lo hondo de sus entrañas. Esta teología ha sido desarro-

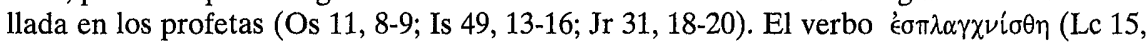
20) debido a su densidad emotiva es de difícil traducción. Diversas traducciones: sentir amor entrañable, partírsele a uno el alma o el corazón, conmoverse en las entrañas, compadecerse. La palabra "entrañas" (en hebreo y griego, rahamim- $\sigma \pi \lambda \alpha \gamma \gamma \chi \nu \alpha$ ) se refiere directamente a sentimientos maternos, los propios de una madre para con su criatura.

76 Marshall, The Gospel. 610. BaIley, Finding, 143. Lo que sorprende es que la actuación compasiva viene de alguien que no se espera. De un patriarca de oriente medio se esperaría que defendiera el honor de la familia; por lo que debía mostrar indignación y enfado. Tiene todo el derecho a no tener nada que ver con su hijo. Pero nada de esto aparece en la parábola, el padre actúa solamente movido por la compasión.

77 BARTOLOMÉ, La alegría, 55-56. No se podía esperar este comportamiento paterno, tenía que resultar sorprendente, por exagerado. De hecho, el hijo no contaba con él (Lc $15,18.21$ ). Ha sido el padre quien ha perdonado y repuesto en su casa al hijo, antes de que éste hubiera expresado su pesar y su propósito. Quien llegaba a casa a servir será sorprendido al ser aceptado como hijo al que honrar. La iniciativa del padre sobrepasa las expectativas y el deseo del hijo. SNODGRASS, Stories, 140. El primer propósito de la parábola es acentuar la compasión, el amor del padre, que refleja analógicamente la actitud de Dios. El v. 20 subraya que el hijo no sólo vuelve a casa sino que también lo hace al padre. Jesús no necesitaba introducir la idea de que Dios acepta a los pecadores, sino que su mensaje del Reino acentuaba que él estaba restaurando Israel, que el perdón se ofrecía ahora y que éste era el tiempo para el arrepentimiento. El Dios que Jesús representa y proclama es precisamente el Dios compasivo y misericordioso que aparece en la parábola. BAILEY, Poet, 181, considera que con esta bienvenida lo que intenta el padre es proteger a su hijo de la hostilidad del pueblo y restaurar su relación con la comunidad. 
pedir perdón ${ }^{78}$. El hijo debía ser acogido en la casa como hijo y señor, por eso se le viste de fiesta, con anillo y sandalias.

Y después sigue la comunidad de mesa con el hijo que certifica su rehabilitación y la alegría del padre, a un mismo tiempo. El padre invita a celebrar un banquete por la vuelta del hijo; quiere que todos se pongan a la mesa, a saber, toda la familia de la casa, de la que nadie se excluye, ni siquiera a los criados ${ }^{79}$.

En esta parábola no se narra nada que aludiera a una búsqueda ${ }^{80}$; y sin embargo, el regreso del hijo es reinterpretado por el padre como un reencuentro (v. 24) "este hijo mío estaba muerto y ha vuelto a la vida, estaba perdido y ha sido hallado". De hecho, el padre, restableciendo la dignidad de hijo al recién llegado, hace mucho más que perdonar su pecado, recuperando al que había perdido, se recupera como padre.

Esta parábola describe con una gran sencillez: así es Dios, tan bueno, tan indulgente, tan lleno de misericordia, tan rebosante de amor. Se alegra del regreso del hijo como el padre que organiza un festín ${ }^{81}$. La parábola es,

78 ConTRERAS, Un padre, 130. El padre perdona con toda su persona, volcándose entero sobre el hijo, sacando los sentimientos de amor de sus entrañas, que se manifestaron en la precipitada carrera de sus pies, en el intenso abrazo sobre su cuello y en los repetidos besos de sus labios. El padre perdona con toda su persona. Y ahora no le deja terminar la confesión que el hijo había preparado.

79 CONTRERAs, Un padre, 264. Se trata ahora de una acción comunitaria, compartida por un sujeto plural, un nosotros que incluye a todos los habitantes de la casa. El verbo $\epsilon u ̉ \phi \rho \alpha i ́ \nu \omega$ aparece aquí para subrayar con su profunda significación la magnificencia de la alegría hecha visible en el banquete de fiesta que el padre manda celebrar. BAILEY, Poet, 186-187. El sacrificar el ternero cebado y no un cabrito es un signo de que la invitación no es solamente para la familia, sino para todo el pueblo. La razón de matar un animal grande es invitar a toda la comunidad.

80 SNODGRASS, Stories, 138-139. Esta parábola es diferente de las anteriores. La oveja y moneda perdidas no hacen nada, y la celebración por el encuentro refleja la alegría del cielo sobre el arrepentido. En esta parábola el pródigo actúa primero. Es cierto que las acciones del padre ocurren antes que el hijo tenga tiempo de confesar y que las acciones del padre están determinadas por su modo de ser. Una vez más, nos encontramos con una parábola que refleja la ilimitada gracia de Dios, pero es también verdad que en esta parábola el padre no busca al hijo perdido, sino que espera. Cuando el hijo vuelve, el padre le sale al encuentro. Por eso se ha interpretado, que las dos primeras parábolas de este capítulo reflejan la soberanía divina y la última refleja la responsabilidad humana. FORBES, The God, 118, subraya que las tres parábolas reflejan la tensión entre la soberanía divina y la respuesta humana que caracterizan las Escrituras. Las dos primeras parábolas reflejan un motivo común acentuando la iniciativa de Dios en la salvación: él nos busca. La tercera parábola subraya la respuesta humana: Dios espera la vuelta del perdido.

81 SNODGRASS, Stories, 140. La parábola es una invitación a la celebración y a la alegría, vv. 23-24 y v. 32. El que estaba perdido ha sido encontrado, por eso hay que celebrarlo. 
al mismo tiempo, una espléndida caracterización del mensaje salvífico de Jesús, el gran predicador del Reino ${ }^{82}$.

Comienza la historia del hijo mayor ${ }^{83}$, cuando la fiesta está iniciada y él lejos de casa, trabajando en el campo haciendo lo que el padre quería y lo que debía. El elemento trágico de la narración se concentra en la figura del hijo mayor. Éste se niega a compartir casa y fiesta con su padre; el hijo mayor sigue estando lejos del padre: reacciona con rabia donde el padre había expresado compasión ${ }^{84}$. El padre tiene que abandonar la casa para ir en su búsqueda. Antes, en busca del hermano menor, la salida fue más precipitada, debido a la más larga lejanía. En ambos casos, los hijos reciben el mismo gesto del padre: la salida en su búsqueda ${ }^{85}$. El padre le suplica ${ }^{86}$ que entre a celebrar la fiesta. La respuesta del hijo es desconsiderada, pero no del todo injusta. Es desconsiderada por no contemplar las razones del padre. Sorprende que el hijo mayor no utilice la palabra "padre", mientras que su hermano la emplea cinco veces, es decir, no acepta que su padre lo sea también del hijo menor, por indigno que éste se haya hecho ${ }^{87}$.

82 SNODGRASS, Stories, 137, es una poderosa presentación de la gracia salvadora de Dios, por eso se la ha considerado un Evangelio dentro del Evangelio, pero es absurdo que contenga todo el Evangelio. Ni ésta ni ninguna otra parábola es un compendio de la teología, aunque nosotros a menudo intentemos hacerlo.

83 JEREMIAS, Interpretación, 98. La parábola fue dicha a hombres que se parecen al hermano mayor, es decir, a hombres que se escandalizan del Evangelio. Jesús les dice: Así de grande es el amor de Dios para con sus hijos perdidos y vosotros estáis sin alegría, sin amor, desagradecidos ante vuestros propios ojos. RAMOS, El reino, 270-271. El hermano que se niega a recibir a su hermano retrata la fidelidad desenfocada de aquellos puritanos que criticaban la compañía de Cristo con los pecadores. Se niegan a entender los planes de la salvación de Dios, colocándose así contra Dios mismo. Estamos hablando de los fariseos.

84 BARTOlOMÉ, La alegría, 63. ConTRERAs, Un padre, 152. El hermano encolerizado constituye el polo opuesto del padre. Antes nos ha dicho que "se conmovieron sus entrañas". Ahora esas entrañas se quedan impasibles, tan duras como piedras. En vez de conmiseración, asoma la cólera.

85 Holgate, Prodigality, 229. Ahora bien, aunque la actitud del padre es la misma, la diferencia entre el hermano mayor y el menor es que el mayor no experimenta ningún tipo de transformación moral ni espiritual. Nada aparece en el hijo mayor que se corresponda a la conversión del hijo menor.

86 RoHrBAugh, "A Dysfunctional", 160. En el medio oriente los padres no suplican a sus hijos, sino que normalmente ordenan. Este comportamiento extraordinario intenta mantener la familia unida, por eso ruega a su hijo mayor que entre a la fiesta. Lo prioritario para el padre es la reconciliación de la familia. Pero en este momento es precisamente el hijo mayor el que se desentiende y no quiere saber nada de su familia. BAILEY, Finding, 171-181. BAILEY, Poet, 195, afirma que rechazar esa invitación y no participar en la comida era un insulto al padre.

87 CONTRERAs, Un padre, 39-40. También el hermano mayor evita a todo trance llamar a su hermano pequeño con la palabra "hermano", y así se refiere a él, diciéndole al padre "tu hijo" (v. 30). El padre, en cambio, le dice corrigiéndolo y recalcando: "tu hermano" (v.32). 
La verdadera causa del alejamiento del hijo mayor está en el acercamiento del padre hacia su hijo menor, del que habla con desprecio. La respuesta del padre, crucial para entender su comportamiento y toda la historia, refleja una ternura no alcanzada en la narración: "hijo, tú siempre estás conmigo, y todo lo mío es tuyo". El padre concluye diciendo que era preciso celebrar y alegrarse. La alegría festiva le viene impuesta: sólo así se confirma como padre del hijo encontrado vivo; repitiéndoles a los dos hermanos la misma invitación los vincula a sí. La alegría del hermano mayor debe nacer de haber recuperado a su hermano; que el padre haya recuperado un hijo, comporta que el auténtico hijo lo reconozca como verdadero hermano ${ }^{88}$. La respuesta queda abierta ${ }^{89}$.

Para los dos hijos la paternidad es gracia: el menor, que la había perdido, la recuperó sin merecerlo; el mayor, que nunca la había gozado, la cues-

88 Nolland, Luke, 791. Contreras, Un padre, 40. Para llegar a ser un buen hijo es preciso sentirse y comportarse como un buen hermano. Y sólo desde la hermandad se puede invocar el nombre del padre. No es posible ser un buen hijo si no se reconoce al hermano; y viceversa, resulta imposible ser buen hermano y no sentir el afecto por el padre. BARTOLOMÉ, La alegría, 118. Sin la recepción del hermano convertido queda cuestionada la alegría de Dios. En el hombre que tiene que convertirse a su hermano cifra su esperanza Dios. El hijo mayor puede rechazar la invitación a la alegría que le hace el padre, pero es la única forma de hacer que triunfe, si la acepta. Holgate, Prodigality, 237. El hermano mayor no alcanza a comprender el verdadero significado de la hermandad. SNODGRASS, Stories, 141, este final abierto funciona como una invitación para que los oyentes tengan la misma actitud hacia los pecadores que el Padre tiene hacia el pródigo.

89 Contreras, Una padre, 300. La parábola queda un tanto en suspense, con un final abierto. Jesús no la ha clausurado, no ha querido ni ha podido. Solamente el lector, quien está leyendo esta historia, debe decidir con toda libertad si quiere o no quiere entrar en casa. Un hijo está fuera, lejos del padre. Otro hijo está dentro, pero su corazón está lejos. Uno es la oveja que se perdió fuera. Otro es la moneda que se perdió dentro (las dos breves parábolas que anteceden). En realidad, son dos hijos perdidos. El padre sale corriendo al encuentro del que regresa caminando. Por mucho que se adelanten nuestros pasos, Dios llega primero y su gracia nos antecede con su perdón. Es un padre que siente en sus entrañas una conmoción que no puede remediar; es padre siempre aún a pesar de todas las razones que la fría razón y el cálculo pueden inventar contra este comportamiento de amor no sólo infinito, sino desmesurado, extravagante, etc. El hijo mayor no quiere entrar. El padre también sale a su encuentro y le habla con amor. LAMBRECHT, J., "A Note on Luke, 15, 11-32", en Luke and his Readers. Festschrift A. Denaux, ed. R. BIERINGER, G. VAN BELLE and J. Verheyden, Leuven University Press, Leuven 2005, 304-305. Lambrecht en esta nota discute el artículo de Worter sobre el capítulo 15 de Lucas quién defiende la exclusión de los fariseos. Nos puede parecer que la parábola del hijo pródigo es una parábola abierta, Jesús dice la parábola para convencer a sus oponentes y ganarlos para el Reino, invitándoles a que cambien su comprensión de Dios. Es cierto que en el Evangelio de Lucas, Jesús muchas veces intenta convencer a sus oponentes, por eso es posible que el evangelista en esta parábola tenga la misma actitud del Jesús histórico. Pero cuando escribe Lucas su Evangelio hay una situación bien diferente, en este tiempo la conversión de los fariseos y los escribas ha desaparecido del horizonte. Para los fariseos y escribas del tiempo de Lucas la parábola del hijo pródigo no es una parábola abierta. 
tionó con su resistencia a aceptarla. La fraternidad recobrada no es sólo motivo de la fiesta del padre ${ }^{90}$, es, además, garantía última de la filiación mantenida en fidelidad. Que la historia acabe sin notar reacción alguna por parte del hijo mayor no ha de hacer olvidar que tampoco el hijo menor reaccionó ante la inesperada acogida del padre. Decisivo para él no es lo que sienten los hijos, en sí mismos y entre sí, sino lo que el padre siente por ellos. No es indiferente que la parábola se cierre sin decir cuál fue la reacción de los hijos a la diferenciada actuación del padre: no es la filiación como relación exclusiva entre padre e hijos lo que ha de ser cuestionado al final, sino una fraternidad por recuperar que crea el empeño de un hombre que, teniendo dos hijos, no quiere perder a ninguno ${ }^{91}$.

Algunos han sugerido que el tema central de esta parábola es la alegría de Dios por encontrar lo perdido. Pero no es completa esta idea, pues falta algo, ya que no hay alegría definitiva en el banquete si el hermano mayor no entra. Por eso es mejor decir que el tema central es "la oferta de un amor costoso a todos"92. El de dentro y el de fuera, encontrado y no encontrado, el amor de Dios como el amor del padre, viene expresado en el propio vaciamiento y humillación para todos en la persona de Cristo ${ }^{93}$.

90 BARTOLOMÉ, La alegría, 92-93. La parábola habla de una oferta incondicionada de perdón y de alegría. El tema es la alegría de la conversión. No hay que pasar por alto que el hijo mayor no es rechazado, sino invitado a aceptar la decisión paterna: también él es sujeto de conversión; que no se narre su entrada en casa, deja en suspenso su participación en la fiesta, pero no la excluye. Y lo que es más decisivo aún, el contenido de la parábola está en conformidad con el mensaje de Jesús y con su actuación pública: Lc 15, 11-32 corresponde con el carácter escatológico de la predicación de Jesús, que invitaba a entrar en el Reino y proponía la conversión como requisito; en la parábola queda reflejada una situación propia de la vida de Jesús, puesto que lo que estaba en discusión era la disposición divina para el perdón dentro del pueblo judío. SNODGRASS, Stories, 135-136. La parábola no es un ataque contra los fariseos y la inconclusa parábola funciona como una invitación a ellos para que cambien de actitud. No entrar en el banquete supone para el hijo mayor una violación del mandamiento de honrar a su padre. Jesús se enfrenta a los fariseos con una imagen de la estrechez de su pensamiento y con la cuestión abierta sobre si el hijo mayor entrará en la casa y se unirá a la celebración. En efecto, Jesús invita a los fariseos a adoptar la actitud de Dios, perdonar a aquellos que desprecian como pecadores, y unirse a la celebración acompañando su proclamación del Reino. SNODGRASs, Stories, 141. El mensaje de la parábola es que Dios acoge tanto a los pecadores como a los buenos. Todos pertenecen a la familia de Dios.

91 Bartolomé, La alegría, 71. LAmBrecht, "A Note", 302. Los dos hijos deben permanecer como hermanos; ambos debían permanecer igualmente como hijos de su padre. Tannheill, C. Robert, Luke, Abindon Press, Nashville, 1996, 244. La alegría de Dios llega a su plenitud cuando un hijo acepta al otro como hermano.

92 BAILEY, Finding, 191. La imagen de Dios como padre compasivo expresa la mejor definición en toda la Escritura. Ese enunciado incluye la oferta de un amor costoso para los que transgreden la ley y para los que la cumplen.

93 BAILEY, Finding, 192. 
También podemos ver una función moral en la parábola. Por medio de la acogida alegre que el padre hace al hijo menor, y la tierna llamada que hace al hijo mayor, Lucas llama a los lectores a ser generosos en su compasión y compasivos en su generosidad. El narra la parábola para ilustrar que la liberalidad es una fuente de alegría y armonía para el individuo y la comunidad 94 .

\section{LA PARÁBOLA DEL BUEN SAMARITANO95}

El relato que comentamos se inscribe en la línea de las disputas a las que se entregaban los rabinos de entonces. Se desarrolla en dos fases, la primera motivada por la pregunta: ¿qué debo de hacer para heredar la vida eterna? (v. 25) y la segunda motivada por la pregunta; ¿quién es mi prójimo ${ }^{96}$. Bovon ${ }^{97}$ nos dice que Jesús al aceptar la pregunta del doctor de la ley, admite que la Escritura necesita una explicación. La posición doctrinal de Jesús, y luego la del Cristianismo, corresponde a una interpretación nueva de las sagradas Escrituras. Nuestra perícopa es un testimonio de las tensiones hermenéuticas que marcaron la vida de las primeras iglesias Cristianas y antes aún la del mismo Jesús.

En la parábola llamada del buen samaritano, el adjetivo "bueno" no está en el texto. La palabra samaritano evoca a un marginado, miembro de una comunidad despreciada ${ }^{98}$, el título tradicional expresa toda una paradoja: el malo no es el que se piensa que es ${ }^{99}$. El uso del adjetivo "bueno"

94 Holgate, Prodigality, 251.

95 Del mismo modo que la parábola del hijo pródigo ilustra el amor del Padre que perdona, la parábola del samaritano invita a los creyentes a la práctica de la caridad. Explicita de este modo el mandamiento del amor al prójimo.

${ }^{96}$ MARSHALl, The Gospel, 440. Las dos secciones se ajustan perfectamente y es difícil imaginar la parábola sin la primera parte para entender el contexto.

97 Bovon, François, El Evangelio según san Lucas II: Lc 9, 51-14,35, traducción Alfonso Ortiz García, Sígueme, Salamanca 2002, 111-112.

${ }^{98}$ Los judíos palestinenses no se trataban con los samaritanos (Jn 4, 9), pues les consideraban cismáticos y eran más odiados que los paganos. Los samaritanos son miembros de una comunidad religiosa que adora el mismo Dios de Israel pero de manera diferente a como lo hace el Judaísmo de Jerusalén. La relación entre judíos y samaritanos era hostil, por la relación entre los dos cultos. Los samaritanos vivían en una proximidad conflictiva con los judíos, que adoraban al Dios de Israel en el templo de Jerusalén. Ellos adoraban el mismo Dios pero en el templo del Monte Garizim.

99 Crossan, John Dominic, "Parable and Example in the Teaching of Jesus", Semeia, 18 (1974), 76. Esta parábola pone en relación dos palabras contradictorias aplicadas a la misma persona: samaritano y prójimo. La idea clave de la historieta exige que no se pueda pronunciar al mismo tiempo: bueno + samaritano. 
tiene sus inconvenientes, ya que va vinculado a la persona, mientras que es la acción del samaritano la que cuenta; además, corre el peligro de reducir la parábola a una lección de moral100.

Ahora bien, la perícopa que comentamos no se limita a la parábola. Ésta se inserta en un debate en el que se quiere responder a la pregunta: ¿qué he de hacer para heredar la vida eterna?101 La parábola intenta dar respuesta a la cuestión concreta: ¿quién es mi prójimo? El mandamiento de amor al prójimo está relacionado con el amor a Dios y con el amor de Dios por nosotros. Así pues, como el mandamiento es doble ${ }^{102}$, Lucas lo ilustra con dos perícopas, una la del samaritano que está vinculada con el amor al prójimo y la otra, de Marta y María que se relaciona con el amor a Dios.

Esta parábola pertenece a la fuente particular del Evangelio de San Lucas, que a diferencia de $Q$ y de Marcos habría articulado la parábola del samaritano sobre la cuestión de los mandamientos esenciales ${ }^{103}$. La narración es una de las parábolas de misericordia que le confieren su tonalidad específica y dan un aura particular a la figura de Jesús ${ }^{104}$.

100 Bovon, El Evangelio II, 109.

101 TANNHEILL, Luke, 181. En la primera parte del diálogo se pone de manifiesto el acuerdo entre Jesús y el doctor de la ley. Están de acuerdo en los asuntos centrales: que el amor a Dios y al prójimo son el centro de la ley y viviendo según ellos se alcanza la vida eterna.

102 Nolland, Luke, 580-582. La importancia del amor al prójimo que se deriva de Lv 19, 18 tuvo un significado importante en la ética judía anterior a Jesucristo. El amor a Dios que se refleja en las palabras del Deu 6, 4-5 era algo común en la piedad judía, que recitaban en la oración diaria del Shema. No está claro que la unión de estos dos mandamientos como resumen de la ley se hiciera, sin influencias helenísticas, en el Judaísmo anterior a Jesús. En los Evangelios aparece claramente la vinculación entre estos dos mandamientos, en este texto de Lucas en boca del doctor de la ley (v. 27). SchotrRoff, Luise, The Parables of Jesus, trad. Por Linda M. Manoley, Fortress Press, Minneapolis 2006, 133134. La discusión y la parábola pertenecen a la rica tradición judía de compasión activa como una expresión del amor a Dios. El amor a Dios y la práctica de la justicia van juntos. Que el amor a Dios se concretiza en el amor al prójimo es algo patente en el Antiguo Testamento y en la tradición posbíblica. Lo que aparece aquí es cómo ese amor puede hacerse práctico y cómo puede crear una relación entre dos personas que sea portadora de vida para ambos: el milagro del amor. SNODGRASs, Stories, 349. Los dos mandamientos son el corazón del Judaísmo y el fundamento del ministerio de Jesús, su credo desde donde todo lo demás surge. El Shema era recitado dos veces al día por todo judío varón, y el amor al prójimo era también central. El desacuerdo entre Jesús y sus contemporáneos no era sobre el significado de los mandamientos del amor, sino sobre su aplicación y extensión.

103 Bovon, El Evangelio II, 113.

104 FitzMYER, El Evangelio III, 277. FitZMYer, A. Joseph, El Evangelio según Lucas, v. I: Introducción general, Cristiandad, Madrid 1986, 435-436. El tercer evangelio presenta una imagen de Jesús con las cualidades de misericordia, amor, alegría y delicadeza. 
Fitzmyer105 considera que lo mismo que otras narraciones típicas de Lucas (cf. Lc. 12,16-21; 16, 19-31; 18, 9-14), se podría pensar también ésta como un "ejemplo" (en el sentido de exemplum en los tratados de Retórica). Se trata de un modelo práctico de comportamiento cristiano, con toda la radicalidad de sus exigencias y con la aprobación o rechazo de determinadas actitudes. El mensaje de la narración no consiste en una cierta analogía con la verdad espiritual, sino en la propia expresividad del relato, en el "ejemplo" mismo que se propone. No obstante, aunque la conclusión de la parábola ("Vete y haz tú lo mismo") puede inclinarnos a considerar la parábola como un ejemplo práctico, muchos exegetas piensan que no es legítimo aplicar a esta parábola el nombre de historieta ejemplar ${ }^{106}$.

La segunda parte de la parábola (vv. 29-37) el doctor de la ley quiere justificarse, y busca una definición del prójimo que corresponda a su conducta habitual, sin duda restrictiva ${ }^{107}$. Desea evitar el reproche implícito: "Tú no lo has hecho", contenido en él "Haz esto y vivirás" (v. 28). Lo que se busca no es tanto la definición de prójimo sino dónde se encuentran los límites del deber del amor dentro de la comunidad. ¿Hasta dónde alcanza esa obligación? Y la parábola responde que el amor no tiene fronteras, nunca podemos decir que hemos amado bastante. No está permitido escoger a los que debemos amar, a los de nuestra raza o cultura, el amor al prójimo se extiende al extranjero o caminante con quien nos encontramos. Lucas, de este modo, criticaba la actitud interesada y por medio de la parábola proponía como modo de actuación una misericordia desinteresada.

Su estructura es muy sencilla: a la situación dada (v. 30) responden dos actitudes contrarias (la mirada indiferente y la negligencia, vv. 31-32, por

105 FITZMYeR, El Evangelio III, 277y Bovon, El Evangelio II, 117, consideran que esta parábola pertenece a los relatos ejemplares, ya que concluye con una invitación a la imitación y está determinada por una visión objetiva y no imaginada de la realidad. Es posible que este sentido de ejemplo haya sido acentuado a lo largo de la tradición en detrimento del alcance metafórico inicial, que como las otras parábolas, tenía una función movilizadora. MARSHALL, The Gospel, 445, ratifica que el samaritano se presenta como un ejemplo a seguir. CROSSAN, "Parable", 72 y 85, considera que es correcto clasificar la parábola del Buen Samaritano como relato ejemplar, más como un ejemplo normativo que como una parábola figurativa, al menos en relación a la tradición y la redacción; aunque esto no provenga de las enseñanzas del Jesús histórico. SNoDgRAss, Stories, 352, piensa que debemos desechar la etiqueta de "example story" aplicada a esta parábola. El buen samaritano no es una historieta metafórica sobre otra realidad, sino que trata de un samaritano compasivo con la intención de enseñar sobre el mandamiento del amor.

106 Forbes, The God, 69. La parábola es más que un cuento ejemplar, lo que queda evidenciado por la elección de personajes, en particular el samaritano como un héroe.

107 El sentido de la pregunta es saber dónde llega la obligación de amar al prójimo, pues era un tema discutido dentro del Judaísmo. Los esenios exigían que había que odiar a todos los hijos de las tinieblas, los fariseos se inclinaban a excluir a los no fariseos. 
una parte; la mirada atenta, la compasión y la acción caritativa, v. 33-35, por otra). La sorpresa proviene de la no-conformidad entre la identidad de las personas y su aptitud. El bien es practicado por aquel a quien se asociaba con el mal, una persona sin nombre y despreciado por su origen ${ }^{108}$.

El sacerdote había terminado seguramente su servicio y regresaba a su casa. En vez de conjugar el amor al prójimo con el servicio de Dios, se olvida de la misericordia, complemento obligado de la piedad. El sacerdote y el levita pasan de largo y no muestran compasión porque la pureza ritual es más importante para ellos que la persona necesitada. En relación con la pureza ritual hay que decir que a los judíos se les pedía que enterraran a los muertos abandonados, e incluso el sumo sacerdote no contraía la impureza por enterrar a un familiar. Y, para la mayoría de los judíos, ni siquiera las leyes de pureza legitimaban no actuar cuando estaba en juego la vida. No sabemos si el levita o el sacerdote se dieron cuenta que el cuerpo estaba malherido o muerto, pero tanto en un caso como en otro, tenían la obligación de enterrarlo a pesar de la impureza, o asistirlo en su necesidad. Tampoco la parábola se detiene en la razón por la que el sacerdote o el levita pasaron de largo, este no era el tema central109.

El relato ha introducido primero a un sacerdote y después a un levita, la narración lucana solamente utiliza las dos categorías de la trilogía tradicional postexilica. Uno normalmente esperaría que el tercer personaje fuera un miembro laico del pueblo de Israel. La sorpresa ocurre cuando dicho personaje es sustituido por un samaritano, un representante al que todos los grupos judíos le excluían de la categoría de prójimo. La paradoja de las paradojas no es solo que el protagonista sea un samaritano, sino que su comportamiento se convierta en modelo de amor al prójimo ${ }^{110}$.

El samaritano que pasa por allí, después de ver a la persona herida, a diferencia de los anteriores se llena de compasión, "se conmovió en las entrañas" ' $\sigma \pi \lambda \alpha \gamma \chi \nu$ í $\sigma \zeta \eta$. Se establece una relación entre el herido y el samaritano. El cuerpo vulnerable de uno despierta el corazón atento del otro, el

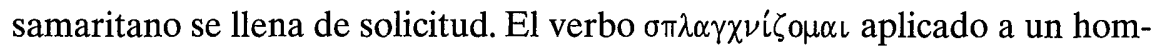

108 Bovon, El Evangelio II, 130. La parábola escoge como figura positiva a un marginal y a un despreciado, silueta negativa de la sociedad judía. La elección de un samaritano sorprende a la gente de bien, que no se esperaba esa reacción del personaje. Por eso se les invita a reflexionar: se descubren menos impecables de lo que creían, más frágiles; se preguntan si no tendrían que hacer ellos lo mismo e ir por el "camino" del encuentro y "hacer lo mismo", es decir, hacerse prójimos con los que se encuentran.

109 SNODGRASs, Stories, 355.

110 GourGES, Michel "The Priest, the Levite and the Samaritan Revisited: A Critical Note on Luke 10: 31-35", Journal of Biblical Literature, 117 (1998), 712-713. 
bre que siente compasión por un semejante quiere indicar según Köster111 la actitud básica y decisiva de toda acción, que, por ser fundamentalmente humana, es esencialmente cristiana. "Conmoverse en las entrañas", "llenarse de compasión", utilizado en otros lugares para evocar la condescendencia de Dios y de Cristo, designa aquí una conducta evangélica (v. 33-35) que el doctor de la ley será llamado a imitar (v. 36). El samaritano comprende la situación, se acerca al herido, sufre con él e intenta aliviar sus dolores. En la respuesta del doctor de la ley: "el que actuó con misericordia" se articula lo interior y lo exterior, el sentimiento (

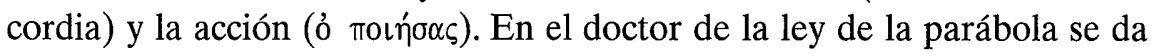
una evolución: primero polémica (v. 25 "¿que he de hacer para tener en herencia la vida eterna?"), luego reservada (v. 29 "¿quién es mi prójimo?"), y finalmente establece una relación con Jesús (v. 37a "el que practicó la misericordia"). Su respuesta verbal está a punto de ser práctica (v. $37 b$ "Vete y haz tú lo mismo"). El escriba y Jesús se han puesto finalmente de acuerdo. Con la pedagogía del maestro ha evolucionado el discípulo112.

La compasión juntamente con la misericordia es la plasmación concreta del amor al prójimo. El primer testimonio que acompaña al concepto de misericordia es el mandamiento de amar al prójimo como a ti mismo, la esencia de la ética cristina, tal como nos la presenta Jesús en la parábola del Samaritano misericordioso. Es precisamente éste el único lugar del Nuevo Testamento, y de la Biblia en general, donde el sentimiento de compasión se usa en conexión con la acción misericordiosa. El Samaritano tuvo misericordia, es el único de los que pasaron por el camino que se conmovió y practicó la misericordia. El texto griego usa la palabra '€’ $\lambda \in \circ \varsigma$, que además de compasión también puede significar misericordia, en esta unión ỏ

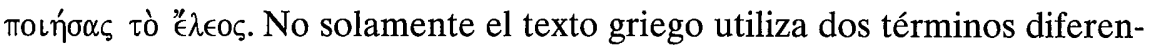
tes para hablar del sentimiento de compasión y de la acción misericordiosa, sino que también el doctor de la ley no solamente repite las palabras usadas por Jesús de "tener misericordia", sino que dicha expresión perfecciona la acción misericordiosa, con lo cual el amor al prójimo se debe definir no solamente desde el sentimiento compasivo, sino también, desde la acción misericordiosa ${ }^{113}$. La parábola del buen Samaritano es, como se ha visto, el único lugar del NT que no sólo utiliza la compasión en conexión

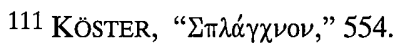

112 Bovon, El Evangelio II, 119-121. TANnheILl, Luke, 184. La compasión del samaritano no es simplemente un sentimiento sino acciones concretas en las que pierde tiempo y recursos para aliviar la necesidad del hombre herido.

113 MALINA, J. Bruce, "“" $€ \in O \varsigma$ y la ayuda social: la utilización de las ciencias sociales en la interpretación del Nuevo Testamento", en BERnABÉ, Carmen y GIL, Carlos (eds.) 
con la actuación misericordiosa nombrada, sino uno de los pocos, en que en realidad la ejemplifica como tal ${ }^{114}$.

Con lo cual podemos concluir diciendo que en las acciones misericordiosas se da el cumplimiento de la ley. La misericordia siempre es una acción, no puede quedar en un sentimiento, sino que conlleva el impulso para pasar a la acción. Así lo vemos en la actuación de Jesús, en la parábola que estamos comentando, y así tiene que estar también en nuestras actuaciones. Con lo que hay que poner en relación la compasión y la misericordia, la primera se refiere a la conmoción interna, y la segunda es la que nos mueve a actuar para aliviar la situación de los afligidos.

El mensaje de la narración se sintetiza en la respuesta que da el jurista. "Prójimo" es todo necesitado que encontramos en nuestro camino115, todo aquel que puede ser objeto de nuestra compasión y de nuestros desvelos, por encima incluso de nuestros vínculos étnicos o de nuestras convicciones religiosas. Aunque las prescripciones sobre la impureza legal que se contraía por contacto con un cadáver formaba también parte del Pentateuco samaritano; pero toda esta legislación no fue obstáculo para que el protagonista de nuestra historia antepusiera sus sentimientos de compasión y de entrega a cualquier clase de restricción legal que, en casos como éste, deben ser superados por la misericordia y el amor. Prójimo es todo necesitado que encontramos en nuestro camino, pero la narración da un significado distinto al término 'prójimo'; en el sentido más exacto, ‘prójimo' es el que muestra benevolencia y 'cordialidad' con respecto a otros. El planteamiento es al revés: ¿Quién de ellos "se hizo prójimo" o-se comportó como tal-del que cayó en manos de los bandidos ${ }^{116}$ ?

Reimaginando los orígenes del cristianismo. Relevancia social y eclesial de los estudios sobre Orígenes del cristianismo. Libro homenaje a Rafael Aguirre en su 65 cumpleaños, Verbo divino, Estella 2008, 121 y 138. Mediante esta escena aprendemos que ser un prójimo implica no sentir " $€ \lambda \in \circ \varsigma$, sino "practicar " $€ \epsilon \in \varsigma$ " con otro. Aunque aquí no es la persona herida la que pide e; leoj; más bien es el samaritano quien voluntariamente practica " $€ \epsilon \in \zeta$, actuando así como si tuviera una deuda con su prójimo. La parábola deja claro que un prójimo no es solamente una persona con quien uno está vinculado por una especie de acuerdo implícito de ayuda recíproca. El ofrecimiento de ayuda, aun sin estar obligado es lo que convierte a quien ayuda en prójimo.

114 Hamburger, Käte, Das Mitleid, Klett-Cotta, Stuttgart 1985, 120.

115 SNODGRASs, Stories, 357. Esta parábola lo que intenta es mostrar que el amor no permite límites a la definición de prójimo. De este modo se destruye cualquier frontera pensada para la compasión y el amor. Cualquier persona, sin excepción, es nuestro prójimo.

116 FITZMYER, El Evangelio III, 279-280. Bovon, El Evangelio II, 121. En el diálogo inicial el doctor de la ley buscaba a un prójimo a quien pudiera amar. En la pregunta de Jesús al resumir la parábola ya no se habla de un prójimo que corre el riesgo de convertir- 
El punto central no fue que el samaritano considerara al hombre caído junto al camino como su prójimo. La parábola no es simplemente una invitación a los oyentes a ayudar a la gente en toda clase de dificultades. La pregunta de Jesús al final no es cómo comportarse con la gente que normalmente desprecias, sino que es más crítica ¿Cuál de los tres fue prójimo del que cayó en manos de los bandidos? o ¿Qué persona en la parábola se comporta como "prójimo" según los mandamientos de la Torah qué dice que debes amar al prójimo como a ti mismo? La respuesta es obvia, pero revolucionaria, el judío caído junto al camino descubrió que el samaritano era su prójimo. Y por deducción, descubre que los otros dos caminantes no fueron prójimos. Esta parábola redefine las fronteras de la alianza de Israel, y de la misma Torah, con grandes implicaciones para el culto del templo. Ante la pregunta ¿qué he de hacer para heredar la vida eterna? La parábola responde con claridad, los de fuera entran en el Reino y los de dentro se quedan fuera. De esta manera, se cuestionaba todo el sistema del templo y el sacrificio ${ }^{117}$.

La parábola subraya que la compasión, la misericordia y el amor son los aspectos clave en la vida de Dios (y por supuesto en el seguimiento de Jesús). Esta parábola evoca la antítesis entre el sacrificio y la misericordia comunes en los escritos proféticos, y es un ejemplo más de que Jesús sustituye el código de la santidad o pureza por el de la misericordia. En relación con el tema de la hostilidad racial, la parábola es muy cercana al mandato de Jesús de amar a los enemigos. No podemos poner barreras al amor ni al perdón. El maestro de la ley parece que buscaba los límites de la obligación de amar al prójimo118.

se en objeto, sino de una persona que se hace prójimo del herido, sujeto activo de una relación. Prójimo es un ser cercano: se trata por tanto de un término relacional; si se establece el contacto, los dos se hacen necesariamente cercanos el uno del otro, el prójimo del otro. ForbEs, The God, 67. El doctor de la ley parece que buscaba una definición empírica de prójimo, Jesús muestra que es en la acción que uno realiza donde se encuentra al prójimo. La vecindad no es una relación estática, sino creativa. Uno se hace prójimo.

117 Wright, Jesus, 306-307. McDonALD, Ian J. H., "Alien Grace (Lc 10, 30-36) The Parable of the Good Samaritan", en Jesus and his Parables. Interpreting the Parables of Jesus Today, ed. V. George ScHILlingTON, T \& T CLARK, Edinburgh 1997, 49. La parábola del buen samaritano es una crítica a los valores del culto, y se puede interpretar como una recapitulación del criticismo profético de la separación del culto del Templo y la justicia social. El criterio fundamental de actuación de Jesús fue más moral que de pureza cúltica. El objetivo de su enseñanza muestra que interpretó la pureza no simplemente en términos de una relación íntima con Dios sino también en términos de la praxis social del pueblo de Dios.

118 SNODGRASS, Stories, 358. 
La compasión ('€ $\lambda \in O \varsigma$ ) del protagonista con el malherido viandante es un ejemplo preciso del "amor al prójimo", enunciado en el v. 27 y recomendado como condición de "vida eterna" en el v. 28. La incorporación de este episodio a la narración evangélica de Lucas da un énfasis particular a ciertas cláusulas del discurso de la llanura, concretamente a las que definen los términos del amor humano (Lc 6, 27-35). También contribuye, a su manera, a la perspectiva de "universalismo" que caracteriza la concepción de Lucas; el horizonte abarca también a un samaritano y le convierte en paradigma para los seguidores de Cristo. La narración sugiere que también el samaritano encontró su camino hacia la "vida eterna". El sacerdote y el levita no es que estuvieran faltos de amor a Dios -la dedicación a su tarea es testimonio fehaciente-; pero cuando se puso a prueba su amor al prójimo se encontró un profundo vacío, mientras que en el samaritano brilló en todo su esplendor ${ }^{119}$.

El NT no es un libro guía para la acción, no nos dice cómo amar al prójimo. El NT habla sobra la identidad cristiana, no sobre las acciones que hay que hacer en cada caso. Los discípulos de Jesús son quienes rechazan poner barreras para identificar a los prójimos $\mathrm{y}$, al contrario, aman hasta a los enemigos. Con esa identidad cada persona debe determinar qué camino de sabiduría expresa mejor esa identidad. Esta parábola tampoco nos dice cómo debemos amar a nuestro prójimo como a nosotros mismos, pero con este ejemplo pone en cuestión nuestra pasividad e indiferencia. Amar al prójimo como a uno mismo es difícil, pero ninguna otra alternativa es válida para los seguidores de Jesús ${ }^{120}$.

La compasión del samaritano es representada como imitación de Dios, como se indica en el verbo en el v. 33 "se conmovió en las entrañas". La gente puede acercar la compasión de Dios a la tierra, hay acciones que hacen presente el amor de Dios, que expresan el amor de Dios a nuestro mundo. Así el año de gracia de Dios, proclamado por Jesús según nos narra Lucas $(4,19)$, llegará a ser una realidad. La tradición judía contiene reflexiones sobre la imitación de Dios ${ }^{121}$.

El énfasis de la narración de Lucas radica en la invitación final. "Pues anda y haz tú lo mismo" (v.37). Y si es importante la figura del samaritano, se debe simplemente al interés de Lucas por subrayar el aspecto universa-

119 FITZMYER, El Evangelio III, 280.

120 SNODGRASS, Stories, 361.

121 SChOTTROFF, The Parables, 136-137. Forbes, The God, 71. El samaritano refleja la misericordia del mismo Dios. Lo cual no significa que el samaritano es una metáfora de Dios, sino que manifiesta la preocupación de Dios para vendar las heridas de los afligidos. En este sentido los discípulos cristianos están llamados a reflejar también la preocupación 
lista; eso es lo que le lleva a buscar en la sociedad palestinense a los seres más despreciados 122 .

El hombre herido junto al camino es llevado a la posada pero no aparece completamente restablecido, el samaritano volverá. La parábola termina con una acción y una conclusión abiertas después de la invitación de Jesús a la acción. El maestro de la ley actuará, la audiencia actuará. La parábola se convierte en una ventana por medio de la cual se hace visible la nueva creación ${ }^{123}$.

Durante toda la tradición ${ }^{124}$ se impuso una interpretación alegórica y cristológica ${ }^{125}$ de esta parábola, hasta el triunfo de la exégesis histórico-crítica. No obstante, no creo que se pueda rechazar la ecuación patrística y medieval de hacer del samaritano una imagen de Jesucristo. El samaritano adopta los sentimientos y repite los gestos del mismo Cristo. Por eso, aunque mantengamos la orientación ética del pasaje, no creo que se pueda infravalorar ni la composición cristológica, de una cristología sobre todo ejemplar, ni el arraigo teológico, de una teología de la economía de la salvación.

y el carácter de Dios, un modo de ser que se manifiesta en la vida y ministerio de Jesús de Nazaret.

122 Fitzmyer, El Evangelio III, 282. BYRne, Brendan, The Hospitality of God. A Reading of Luke's Gospel, The Liturgical Press, Collegeville, Minnesota 1989, 101. No es cuestión de poner límites a la noción de "prójimo" o ver hasta donde se extienden las obligaciones del precepto del amor, como parece entender el doctor de la ley. Hay que imitar la hospitalidad mostrada por el extranjero que rompe las barreras étnicas y prejuicios religiosos para ayudar a quien se encuentra necesitado. El concepto de prójimo deja de ser una etiqueta que puedo o no puedo aplicar a otro, y se convierte en una vocación que tengo que vivir activamente.

123 SCHOTTROFF, The Parables, 137.

124 Roukema, Riemer, "The Good Samaritan in Ancient Christianity", Vigiliae Christianae 58 (2004), 56-74. Este artículo repasa la interpretación alegórica de la parábola del Buen Samaritano en la tradición patrística: Ireneo, Clemente, Orígenes, Ambrosio, Agustín, etc. No obstante, el autor considera que aunque la interpretación de la Escritura e incluso de las parábolas sucede en el NT, no existe indicio alguno de que Lucas comprenda la parábola del Buen Samaritano como una alegoría de la salvación de Cristo a los pecadores.

125 MCDONALD, "Alien Grace", 39. Todos los padres de la Iglesia hicieron una interpretación alegórica de esta parábola. La figura del ayudante en toda su extrañeza actúa con toda compasión y generosidad. La invitación de "vete y haz tú lo mismo" es una ofrecimiento a imitar a Jesucristo, a actuar en relación a los otros en el espíritu de la gracia y la gratuidad. SNodgrass, Stories, 347. La exégesis patrística unánimemente está de acuerdo en que la parábola es una alegoría de la salvación. Bovon, El Evangelio II, 110. Esta interpretación cristológica es válida pues se arraiga en Dios compasivo y se despliega en la Iglesia, cuyos miembros prosiguen con su fe y su práctica los gestos caritativos del Señor. 
